\title{
Late Holocene environmental change in Celestun Lagoon, Yucatan, Mexico
}

\author{
Kyle Hardage (iD) - Joseph Street • Jorge A. Herrera-Silveira • Ferdinand K. J. Oberle • \\ Adina Paytan
}

Received: 22 August 2019/Accepted: 19 November 2021/Published online: 18 December 2021

(C) The Author(s) 2021

\begin{abstract}
Epikarst estuary response to hydroclimate change remains poorly understood, despite the wellstudied link between climate and karst groundwater aquifers. The influence of sea-level rise and coastal geomorphic change on these estuaries obscures climate signals, thus requiring careful development of paleoenvironmental histories to interpret the paleoclimate archives. We used foraminifera assemblages, carbon stable isotope ratios $\left(\delta^{13} \mathrm{C}\right)$ and carbon:nitrogen $(\mathrm{C}: \mathrm{N})$ mass ratios of organic matter in sediment cores to infer environmental changes over the past 5300 years in Celestun Lagoon, Yucatan, Mexico. Specimens $(>125 \mu \mathrm{m})$ from
\end{abstract}

Supplementary Information The online version contains supplementary material available at https://doi.org/10.1007/s10933-021-00227-4.

K. Hardage $(\bowtie) \cdot$ J. Street · A. Paytan

University of California Santa Cruz, Santa Cruz, USA

e-mail: khardage@ucsc.edu

J. Street

e-mail: jhstreet75@gmail.com

A. Paytan

e-mail: apaytan@ucsc.edu

J. A. Herrera-Silveira

CINVESTAV-IPN, University of Mérida, Mérida, Mexico

e-mail: jorge.herrera@ cinvestav.mx

F. K. J. Oberle

United States Geological Survey, Santa Cruz, USA

e-mail: foberle@usgs.gov modern core top sediments revealed three assemblages: (1) a brackish mangrove assemblage of agglutinated Miliammina and Ammotium taxa and hyaline Haynesina (2) an inner-shelf marine assemblage of Bolivina, Hanzawaia, and Rosalina, and (3) a brackish assemblage dominated by Ammonia and Elphidium. Assemblages changed along the lagoon channel in response to changes in salinity and vegetation, i.e. seagrass and mangrove. In addition to these three foraminifera assemblages, lagoon sediments deposited since 5300 cal yr BP are comprised of two more assemblages, defined by Archaias and Laevipeneroplis, which indicate marine Thalassia seagrasses, and Trichohyalus, which indicates restricted inland mangrove ponds. Our data suggest that Celestun Lagoon displayed four phases of development: (1) an inland mangrove pond (5300 BP) (2) a shallow unprotected coastline with marine seagrass and barrier island initiation (4900 BP) (3) a protected brackish lagoon (3000 BP), and (4) a protected lagoon surrounded by mangroves (1700 BP). Stratigraphic (temporal) changes in core assemblages resemble spatial differences in communities across the modern lagoon, from the southern marine sector to the northern brackish region. Similar temporal patterns have been reported from other Yucatan Peninsula lagoons and from cenotes (Nichupte, Aktun Ha), suggesting a regional coastal response to sea level rise and climate change, including geomorphic controls (longshore drift) on lagoon salinity, as observed today. Holocene barrier 
island development progressively protected the northwest Yucatan Peninsula coastline, reducing mixing between seawater and rain-fed submarine groundwater discharge. Superimposed on this geomorphic signal, assemblage changes that are observed reflect the most severe regional wet and dry climate episodes, which coincide with paleoclimate records from lowland lake archives (Chichancanab, Salpeten). Our results emphasize the need to consider coastal geomorphic evolution when using epikarst estuary and lagoon sediment archives for paleoclimate reconstruction and provide evidence of hydroclimate changes on the Yucatan Peninsula.

Keywords Yucatan - Celestun · Paleoecology · Mangrove $\cdot$ Estuary $\cdot$ Foraminifera

\section{Introduction}

Epikarst estuaries provide sediment archives that record sea level rise, storm histories, and coastal environmental change. Like siliciclastic estuary systems, epikarst estuaries back-step landward in response to Holocene sea-level rise and changes in coastal geomorphology such as barrier island progradation. However, epikarst estuaries are generally linked to a groundwater system, and hence modified by catchment hydrochemistry, and thus also respond to ocean-atmosphere forced changes in hydroclimate. Epikarst groundwater systems are important geologic features of the Caribbean region (van Hengstum et al. 2011, 2020; Collins et al. 2015; Tamalavage et al. 2018), where environmental change affects humans and natural ecosystems dependent on karst groundwater resources (Gabriel et al. 2009; Perry et al. 2011; Peros et al. 2015; Jaijel et al. 2018). Coastal epikarst systems have recently been recognized as important paleoclimate archives (Gabriel et al. 2009; van Hengstum et al. 2018), but interpreting climate signals in these complex systems requires a robust understanding of the sedimentary processes that occur in epikarst estuaries and associated lagoons.

Here we present the longest paleoenvironmental record to date from Celestun Lagoon, a large epikarst estuary (sometimes locally called caletas) on the Yucatan Peninsula, Mexico. The microfossil and vegetation records span the last 5300 years and reflect changes in buildup of dune-ridge complexes and lagoon landward back-step progression, development of mangrove forest, storm and current events, and groundwater spring discharge and reveal an estuary's sensitivity to climate and coastal changes in the peninsula lowlands.

The Yucatan Peninsula is a carbonate platform that is dominated by karst geomorphology (Perry et al. 1995; Perry et al. 2003), where rainfall percolates rapidly into groundwater (within months), flows toward the coasts and discharges as submarine springs (Herrera-Silveira 1994; Perry et al. 2003). In the north Yucatan Peninsula, the discharge location of these submarine springs is strongly controlled by the Chicxulub impact crater, which focuses discharge into the Celestun and Dzilam Lagoons (Perry et al. 2002; Perry et al. 2003; Bauer-Gottwein et al. 2011). Climate on the Yucatan Peninsula is seasonal subtropical, with most rainfall occurring from June to October (Herrera-Silveira 1994; BauerGottwein et al. 2011). Seasonality of precipitation is driven primarily by intra-annual migration of the Intertropical Convergence Zone about the equator (Hodell et al. 1991; Hughen et al. 1996; Haug et al. 2001), but inter-annual variability in rainfall is influenced by additional ocean-atmosphere circulation patterns, including the North Atlantic Subtropical High pressure zone in the Atlantic, Walker circulation across the Pacific, and solar insolation across both ocean basins (Bond et al. 2001; Laskar et al. 2004; Sutton and Hodson 2005; Douglas et al. 2016a; Bhattacharya et al. 2017). The peninsula is also characterized by steep gradients in precipitation, with rainfall up to $2000 \mathrm{~mm} \mathrm{y}^{-1}$ in the southern highlands to less than $500 \mathrm{~mm} \mathrm{y}^{-1}$ in the northern lowlands (Bauer-Gottwein et al. 2011; Metcalfe et al. 2015).

Regional climate variability, together with local hydrologic conditions, is expressed in paleoclimate records across the Yucatan Peninsula from lake and cenote sediment cores (Hodell et al. 1995, 2005; Leyden et al. 1996; Douglas et al. 2016b), Caribbean coastal cave deposits (Gabriel et al. 2009; van Hengstum et al. 2010; Collins et al. 2015), and speleothems (Webster et al. 2007; Medina-Elizalde et al. 2010; Kennett et al. 2012; Douglas et al. 2016b; Akers et al. 2016). These records differ in the timing and severity of recorded drought events, making it difficult to reconstruct past atmospheric circulation and raising the need for an integrated spatio-temporal 
rainfall record. New records from coastal lagoons that represent integrated regional climate (via groundwater within a large catchment) could reconcile some of the discrepancies among other paleoclimate archives.

Foraminifera assemblages and bulk sediment organic matter $\delta^{13} \mathrm{C}$ and $\mathrm{C}: \mathrm{N}$ elemental ratios are useful tools for exploring coastal paleoecology and environmental conditions that respond to climate changes. Modern foraminifera species are distributed along gradients of salinity, wave energy, water stratification, and substrate type, making them sensitive indicators of change in the physical and chemical environment (Debenay and Guillou 2002; Murray 2006; Schönfeld et al. 2012). Coastal paleoenvironmental reconstructions from foraminifera utilize groups or clusters of taxa to represent a particular environment (e.g., brackish estuary, protected lagoon, open coast) and/or individual species to indicate specific habitat (e.g., mangrove swamp, seagrass beds, suboxic sediment) (Sen Gupta 1999). Both methods have been used to characterize the coastal environment in the Yucatan Peninsula and broader Caribbean region. In particular, tropical estuaries are characterized by a landward (estuary's head) finesediment assemblage containing Ammotium, Miliammina, and Trochammina spp., which transitions to brackish mixed assemblages of Ammonia, Elphidium, and Quinqueloculina spp., followed by an ocean assemblage containing Bolivina and Rosalina spp., among other marine taxa toward the estuary opening to the ocean (estuary mouth) (Debenay and Guillou 2002).

In the carbonate-rich mangrove-dominated estuaries of the Caribbean, species richness increases with distance from sheltered coastal lagoons, where a few agglutinated taxa dominate, to tidal flats and a shallow inner shelf, where more diverse hyaline and porcelaneous taxa live. For example, Trochammina and other agglutinated taxa live in fringing mangroves of Puerto Rico whereas Rosalina, Peneroplis, and Archaias live far from protective mangroves in carbonate mud flats and shallow carbonate lagoons (Culver 1990). Changes in the coastal environment affect this distribution, as in Nichupte Lagoon, Quintana Roo (northeast Yucatan Peninsula coast), where barrier islands restricted circulation and changed the foraminifera assemblages from marine genera such as Triloculina and Quinqueloculina to brackish-tolerant Ammonia and Elphidium (Hart and
Kaesler 1986). In addition to salinity change caused by reduced connectivity with seawater, restricted circulation results in diurnal or seasonal fluctuations in $\mathrm{pH}$, temperature, and oxygen, with a corresponding decrease in foraminifera species diversity (Hart and Kaesler 1986; Sen Gupta 1999). Circulation restriction has been observed in multiple lagoons along the northeast Yucatan Peninsula coast, with significant changes in sediment deposition and faunal response (Brady 1972). Ecosystem changes based on specific indicator species have also been used around the Caribbean, for example Archaias angulatus and Peneroplis proteus are used to identify coral reef and seagrass habitat because these species require marine salinities and seagrass beds of Thalassia (Sen Gupta 1999; Gischler and Hudson 2004). The agglutinated Miliamina fusca requires hyposaline muddy environments, and assemblages composed entirely of agglutinated specimens often mark inner mangrove swamps (Sen Gupta 1999).

Carbon isotopes $\left(\delta^{13} \mathrm{C}_{\mathrm{org}}\right)$ and $\mathrm{C}: \mathrm{N}$ elemental ratios of sediment organic matter $(\mathrm{OM})$ are robust tracers of the sources of $\mathrm{OM}$ to the lacustrine and marine sediments because of the strong difference in $\delta^{13} \mathrm{C}_{\text {org }}$ and $\mathrm{C}: \mathrm{N}$ of terrestrial plants relative to seagrass and marine phytoplankton (Gonneea et al. 2004; Lamb et al. 2006). These variables have been used in circum-Caribbean carbonate environments to infer changes in vegetation and to determine the causes for such changes, including Maya agricultural practices (C3 vs. C4 plants), climate conditions (moist vs. arid), and sea level rise (mangroves) (Gonneea et al. 2004; Polk et al. 2007; van Hengstum et al. 2010). Specifically, $\delta^{13} \mathrm{C}, \mathrm{C}: \mathrm{N}$, and microfossil assemblage records were used to elucidate changes in climate variability and its effect on dominant lowlying wetland vegetation and karst sinkhole and cave flooding events during wet climate periods (Polk et al. 2007; van Hengstum et al. 2010, 2020; Tamalavage et al. 2018). These studies demonstrated the utility of combining OM variables with other hydroclimate and sea level proxies (e.g., $\delta^{18} \mathrm{O}$, microfossils, and peat) for documenting ecologic and hydroclimate changes.

In this study we present data on modern benthic foraminifera assemblages and a 5300-year record of foraminifera assemblage changes, $\delta^{13} \mathrm{C}$, and $\mathrm{C}: \mathrm{N}$ in sediment from Celestun Lagoon, Yucatan, Mexico. We inferred the paleoenvironmental history of the 
lagoon with a particular focus on factors that control lagoon salinity. We assessed the causes of the changes in salinity (e.g., sea level rise and changes in coastal geomorphology) and then compared our record to other paleoenvironmental and paleoclimate records from the peninsula.

\section{Site description}

Celestun Lagoon is a narrow $(0.5-2.4 \mathrm{~km})$ and long $(21.2 \mathrm{~km})$ estuarine lagoon on the northwest coast of the Yucatan Peninsula in southern Mexico (Fig. 1a). The lagoon is currently protected from ocean waves by a series of coquina dune ridges about $30 \mathrm{~km}$ long (Fig. 1b, Lowery and Rankey 2017). The lagoon interior is characterized by autochthonous carbonate sediments that range in size from fine carbonate muds in the protected northern lagoon to coarse mollusk and gastropod shells and fragments near the southern lagoon, which opens to the ocean. Benthic foraminifera are found throughout the lagoon. The lagoon depth ranges from $0.5 \mathrm{~m}$ in the north to $3 \mathrm{~m}$ in the south, and bottom sediments in the center of the lagoon remain submerged at low tide (Young et al. 2008; Lowery and Rankey 2017). Red and black mangroves, Rhizophora mangle and Avicennia germinans, respectively, fringe all sides of the lagoon, and abundant, brackish-water-tolerant seagrass beds (Halodule wrightii, Ruppia mexicana) dominate the central lagoon channel (Herrera-Silveira et al. 1998). These polyhaline flora and fauna are supported by submarine groundwater springs that discharge brackish (salinity of 3-9 psu) groundwater predominantly in the northern lagoon, giving the lagoon its estuarine characteristics, with a persistent, but seasonally variable salinity gradient (Herrera-Silveira 1996; Gonneea et al. 2004). Peak groundwater discharge into Celestun Lagoon, which occurs in December, lags peak rainfall by one to two months (Perry et al. 2002), and prolonged wet periods accompany prolonged low-salinity conditions in the northern lagoon (Herrera-Silveira 1994; Herrera-Silveira et al. 1998). The interior of Celestun Lagoon is a low-energy settling basin, and the exterior (ocean side, Fig. 1c) is high-energy, characterized by ocean currents and winter storm waves that cause longshore transport of bioclastic carbonate sediments. Longshore drift transports sediment southward along the outer west bank of the lagoon, resulting in net barrier island
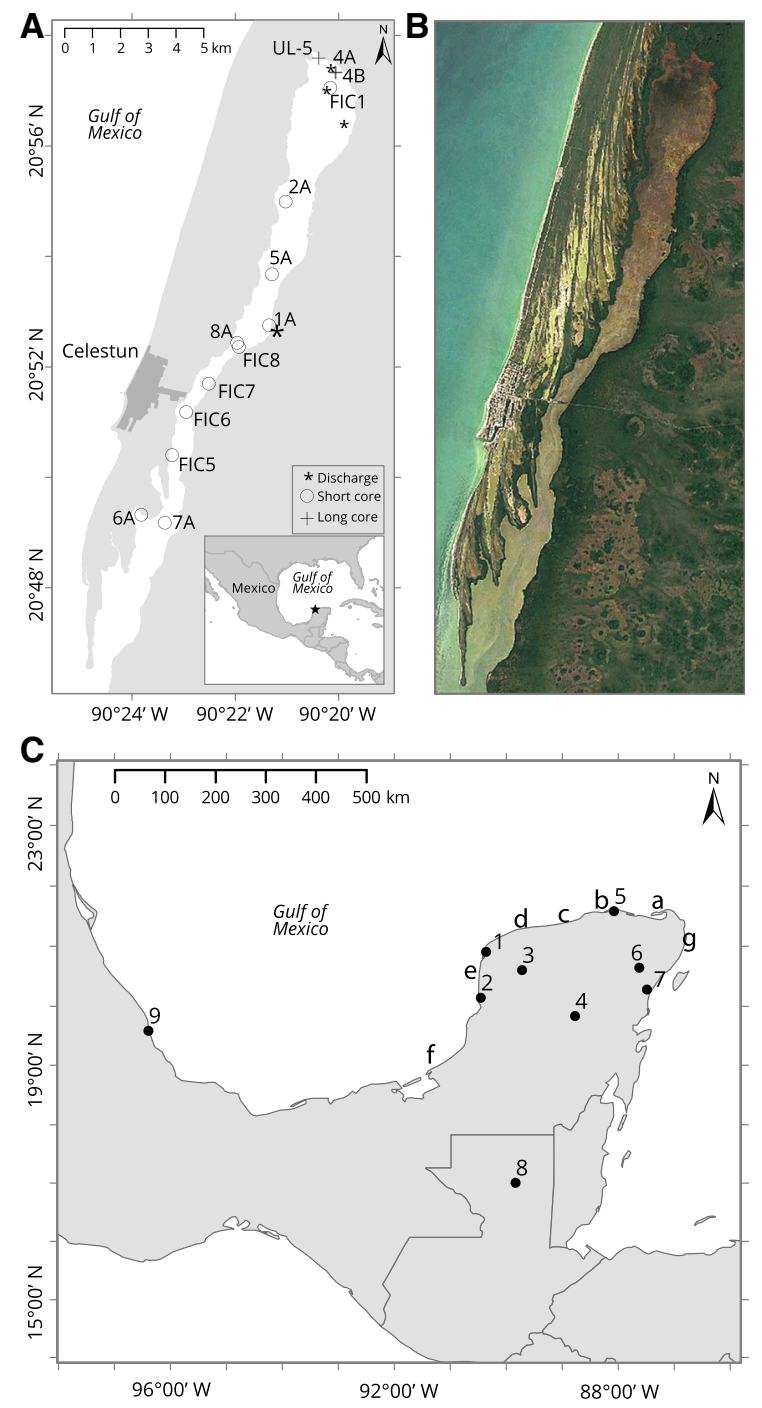

Fig. 1 A Map of Celestun Lagoon field location with sample sites from the northern lagoon to the southern lagoon (open to the ocean) and groundwater spring discharge locations. Site names derive from expeditions (Table 1), and water samples were measured at each site. B Satellite imagery of Celestun Lagoon showing differing land features of the east and west banks. Scale and direction areas in A. C Field sites for comparison in Fig. 8. 1 Celestun Lagoon (this study), 2 Los Petenes (Roy et al. 2017), 3 Aguada X'caamal (Hodell et al. 2005), 4 Lake Chichancanab (Hodell et al. 1995), 5 Ria Lagartos (Aragón-Moreno et al. 2012), 6 Punta Laguna (Curtis et al. 1998), 7 Aktun Ha (ven Hengstrum et al. 2010), 8 Lake Puerto Arturos (Wahl et al. 2014), 9 La Mancha Lagoon (Arellano-Torres et al. 2019). Letters are coastal sites with geomorphic features similar to Celestun Lagoon: a Holbox, b Ria Lagartos, c Dzilam de Bravo, d Progreso, e Isla Arena, f Terminos, g Nichupte 
Table 1 Sediment sampling sites, cores taken, and modern environmental parameters measured at each site

\begin{tabular}{|c|c|c|c|c|c|c|c|c|c|c|c|}
\hline Site & Core* & $\begin{array}{l}\text { Interval } \\
(\mathrm{cm})\end{array}$ & $\begin{array}{l}\text { Refusal } \\
(\mathrm{cm})\end{array}$ & $\begin{array}{l}\text { Expedition } \\
\text { Year }\end{array}$ & Latitude & Longitude & $\begin{array}{l}\text { Distance }^{\dagger} \\
(\mathrm{km})\end{array}$ & $\begin{array}{l}\text { Salinity } \\
\text { (psu) }\end{array}$ & $\begin{array}{l}\text { Temperature } \\
\left({ }^{\circ} \mathrm{C}\right)\end{array}$ & $\begin{array}{l}\delta^{13} \mathrm{C}_{\mathrm{org}} \\
(\% \circ)\end{array}$ & $\begin{array}{l}\mathrm{C}: \mathrm{N} \\
\text { (mass) }\end{array}$ \\
\hline \multirow[t]{2}{*}{ UL-5 } & UL-5-1 & $0-110$ & - & 2006 & 20.9589 & -90.3406 & 0.21 & 23 & - & -24.17 & 8.8 \\
\hline & UL-5-2 & $110-200$ & & & & & & & & & \\
\hline \multirow[t]{3}{*}{$4 \mathrm{~A}$} & 4A-1P-1 & $0-148$ & $\sim 300$ & 2009 & 20.9548 & -90.3354 & 0.72 & 29 & 32.3 & -23.74 & 8.8 \\
\hline & $4 \mathrm{~A}-2 \mathrm{~B}-1$ & $148-262$ & & 2009 & 20.9548 & -90.3354 & 0.72 & 29 & 32.3 & & \\
\hline & $4 \mathrm{~A}-3 \mathrm{~L}-1$ & $251-262$ & & 2009 & 20.9548 & -90.3354 & 0.72 & 29 & 32.3 & & \\
\hline \multirow[t]{3}{*}{$4 B$} & $4 B-1 P-1$ & $0-67$ & $\sim 300$ & 2009 & 20.9548 & -90.3354 & 0.72 & 29 & 32.3 & -23.74 & 8.8 \\
\hline & 4B-2B-1 & $67-184$ & & 2009 & 20.9548 & -90.3354 & 0.72 & 29 & 32.3 & -23.74 & 8.8 \\
\hline & 4B-3L-1 & $184-240$ & & 2009 & 20.9548 & -90.3354 & 0.72 & 29 & 32.3 & -23.74 & 8.8 \\
\hline FIC1 & FIC15-1 & $0-30$ & - & 2015 & 20.9501 & -90.3370 & 1.30 & 16 & 28.6 & -23.64 & 8.9 \\
\hline $2 \mathrm{~A}$ & 2A-1P-1 & 0-119 & - & 2009 & 20.9157 & -90.3513 & 5.51 & 26 & 32.8 & -22.92 & 9.5 \\
\hline $5 \mathrm{~A}$ & 5-SPC & $0-30$ & $\sim 187^{\ddagger}$ & 2009 & 20.8938 & -90.3558 & 8.20 & 23 & 31.4 & - & - \\
\hline $1 \mathrm{~A}$ & 1A-1P-1 & $0-106$ & $\sim 107$ & 2009 & 20.8783 & -90.3567 & 10.09 & 14 & 23.7 & -22.14 & 10.3 \\
\hline $8 \mathrm{~A}$ & 8A-1P-1 & $0-135$ & $\sim 143$ & 2009 & 20.8731 & -90.3670 & 10.73 & 25 & 30.6 & -22.03 & 10.4 \\
\hline FIC8 & FIC15-21 & $0-30$ & - & 2015 & 20.8718 & -90.3666 & 10.89 & 23 & 28.2 & -22.00 & 10.4 \\
\hline FIC7 & FIC15-20 & $0-30$ & - & 2015 & 20.8607 & -90.3762 & 12.24 & 24 & 27.9 & -21.77 & 10.6 \\
\hline FIC6 & FIC15-19 & $0-30$ & - & 2015 & 20.8522 & -90.3835 & 13.29 & 25 & 28.7 & -21.59 & 10.8 \\
\hline FIC5 & FIC15-18 & $0-30$ & - & 2015 & 20.8392 & -90.3880 & 14.88 & 31 & 28.3 & -21.32 & 11.1 \\
\hline $6 \mathrm{~A}$ & $6 \mathrm{~A}-1 \mathrm{~L}-1$ & $0-81$ & $\sim 209^{\ddagger}$ & 2009 & 20.8216 & -90.3978 & 17.03 & 29 & 26.9 & -22.19 & 11.0 \\
\hline $7 \mathrm{~A}$ & 7A-1P-1 & $0-149$ & $\sim 161$ & 2009 & 20.8197 & -90.3904 & 17.39 & 33 & 31.2 & -20.89 & 11.5 \\
\hline
\end{tabular}

\footnotetext{
* For cores collected in 2009, coring device is denoted after the first dash as $\mathrm{P}=$ piston, $\mathrm{B}=\mathrm{Bolivia}, \mathrm{L}=\mathrm{Livingstone}$

* Refusal depth is from long cores driven at same site but not used in this study

$\dagger$ Distance is from the northern lagoon near $(0 \mathrm{~km})$ to the southern lagoon $(20 \mathrm{~km})$

Core 5-SPC and cores FIC15 series are short push cores
}

elongation rates of about $6 \mathrm{~m} \mathrm{y}^{-1}$ (Lowery and Rankey 2017). The east lagoon bank is sheltered from longshore transport and dominated by flooded mangrove forest.

\section{Materials and methods}

\section{Sediment and water sampling}

Three expeditions to Celestun Lagoon (May 2006, June 2009, and May 2015, Table 1) were undertaken to collect sediment cores and contemporaneous in situ water salinity and temperature data, the latter measured with a Yellow Springs Instruments model 63 , handheld sonde. Water depth was not measured, but was estimated at about $50 \mathrm{~cm}$ for all core sites. Short cores $(n=6)$ were collected using $30-\mathrm{cm}$ push cores along a lagoon transect from north to south (Fig. 1a, Table 1). Push cores were immediately extruded and sectioned into 2-cm intervals to ensure sufficient mass for ${ }^{210} \mathrm{~Pb}$ dating. Longer sediment cores $(n=8)$ were collected using Bolivia and Livingstone piston corers (LacCore, University of Minnesota) and imaged with a Geotek Corescan-V camera provided by the National Lacustrine Core Facility (Minnesota, USA, Fig. 2). Core 4A was collected in three drives, and core 4B, $3 \mathrm{~m}$ from core $4 \mathrm{~A}$, was also collected in three drives (Table 1), but used only for additional radiocarbon dating. Bulk wet density was measured with a gamma densitometer for cores 4A and 4B (Fig. 2) and used in Corelyzer software v.2.0.4 to match radiocarbon ages from core $4 \mathrm{~B}$ to appropriate depths in core 4A. Bedrock is estimated to be about $3 \mathrm{~m}$ deep in the northern lagoon based on clinking sounds heard from coring (Livingstone, $298 \mathrm{~cm}$ total recovery, not used in this study) $0.7 \mathrm{~km}$ west of $4 \mathrm{~A}$ and $4 \mathrm{~B}$. Auxiliary core UL-5 was collected in 2 drives (200 cm total length, Fig. S1) and was used to corroborate age-depth models and 


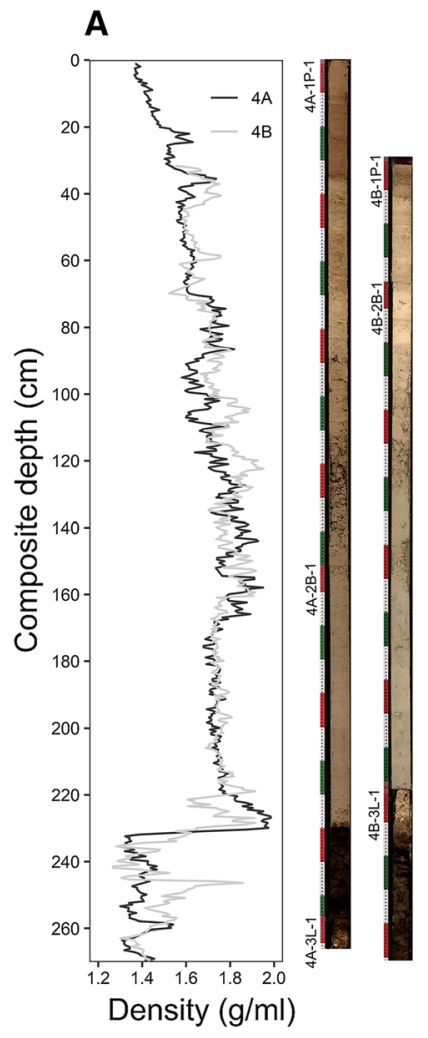

Fig. 2 A Downcore density measured in cores from sites 4A and $4 \mathrm{~B}$ to determine composite depth profile for radiocarbon ages. Peat layer begins at $229 \mathrm{~cm}$. B Top $50 \mathrm{~cm}$ of cores from

general trends observed in core 4A. Sediment cores $4 \mathrm{~A}$ and UL-5 were subsampled in 1-cm sections every $\sim 5 \mathrm{~cm}$, split into aliquots, and separated for $\mathrm{OM}$ $\delta^{13} \mathrm{C}$ and $\mathrm{C}: \mathrm{N}$ mass ratio analyses and benthic foraminifera assemblages.

\section{Chronology}

Basal peat and terrestrial macro-organics (roots, leaves, and seeds) were picked from wet-sieved sediments from cores at sites $4 \mathrm{~A}$ and $4 \mathrm{~B}$ and used for radiocarbon dating. Autochthonous organic carbon (e.g., seagrass) was avoided where identifiable because of potential carbon reservoir effects that occur in karst systems (Fletcher et al. 2017). All radiocarbon dates $(n=15$, Table 2$)$ were calibrated to calendar years using IntCal13 as detailed in Blaauw and Christen (2011). Site 5A was chosen for measuring ${ }^{210} \mathrm{~Pb}$ activity because of its distance from the ocean to the south and from active flamingo flocks to the north, which can enhance bioturbation locations in Fig. 1. Coarse $(>500 \mu \mathrm{m})$ bioclastic sand and shell layer is boxed at $30 \mathrm{~cm}$. Note increasing thickness from north $(4 \mathrm{~A})$ to south $(6 \mathrm{~A})$

and sediment mixing. ${ }^{210} \mathrm{~Pb}$ activity $(\mathrm{n}=7)$ was determined using 10-mL samples of homogenized bulk sediment sealed in vials for $24 \mathrm{~h}$ and measured in a high-purity germanium (HPGe) well detector, using established methods and calibration reference materials (Swarzenski et al. 2006). Sediment accretion rates were calculated from ${ }^{210} \mathrm{~Pb}_{\text {excess. }}$ We excluded ${ }^{210} \mathrm{~Pb}_{\text {excess values from the upper mixed }}$ $5 \mathrm{~cm}$ of the sediment and used values below $6 \mathrm{~cm}$, which show a clear log-linear profile of ${ }^{210} \mathrm{~Pb}_{\text {excess }}$ with depth. We set $0 \mathrm{~cm}$ depth to -59 years before present, where 1950 is 0 years before present. The age-depth model (Fig. 3) was developed using the $\mathrm{R}$ package 'rbacon' v. 2.4.0, which uses Bayesian inference models of the radiocarbon and ${ }^{210} \mathrm{~Pb}$ derived sediment accumulation rate (Blaauw and Christen 2011). Radiocarbon data from sites $4 \mathrm{~A}$ and

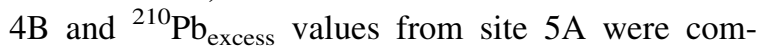
bined to create the most probable age-depth model for core 4A. One radiocarbon age of 1485 at depth of $30.5 \mathrm{~cm}$ (Table 2) was excluded from the model 
Table 2 Radionuclide data used in age-depth models in the $\mathrm{R}$ package rbacon

\begin{tabular}{|c|c|c|c|c|c|c|c|c|}
\hline Lab ID & Site & Core & $\begin{array}{l}\text { Interval } \\
(\mathrm{cm})\end{array}$ & $\begin{array}{l}\text { Composite } \\
\text { depth }(\mathrm{cm})\end{array}$ & $\begin{array}{l}{ }^{210} \mathrm{~Pb}_{\text {excess }} \\
\left(\mathrm{dpm} \mathrm{g} \mathrm{g}^{-1}\right)\end{array}$ & $\begin{array}{l}{ }^{210} \mathrm{~Pb}_{\text {excess }} \\
\text { error }\left(\mathrm{dpm} \mathrm{g}^{-1}\right)\end{array}$ & $\begin{array}{l}{ }^{14} \mathrm{C}_{\text {uncalibrated }} \\
\text { (yr) }\end{array}$ & $\begin{array}{l}{ }^{14} \mathrm{C}_{\text {uncalibrated }} \\
\text { error }(\mathrm{yr})\end{array}$ \\
\hline- & $5 \mathrm{~A}$ & 5-SPC & $0-2$ & 1 & 0.280 & 1.624 & - & - \\
\hline- & $5 \mathrm{~A}$ & 5-SPC & $2-4$ & 3 & 1.605 & 1.076 & - & - \\
\hline- & $5 \mathrm{~A}$ & 5-SPC & $4-6$ & 5 & 1.097 & 1.018 & - & - \\
\hline- & $5 \mathrm{~A}$ & 5-SPC & $6-8$ & 7 & $1.836^{*}$ & 0.972 & - & - \\
\hline- & $5 \mathrm{~A}$ & 5-SPC & $8-10$ & 9 & $1.512 *$ & 1.191 & - & - \\
\hline- & $5 \mathrm{~A}$ & 5-SPC & $10-12$ & 11 & $0.962 *$ & 1.336 & - & - \\
\hline- & $5 \mathrm{~A}$ & 5-SPC & $12-14$ & 13 & $0.517 *$ & 0.927 & - & - \\
\hline CAMS \#177,919 & $4 \mathrm{~A}$ & $4 \mathrm{~A}-1 \mathrm{P}-1$ & $30-31$ & 30.5 & - & - & $1485^{\dagger}$ & 30 \\
\hline CAMS \#150,117 & $4 \mathrm{~A}$ & $4 \mathrm{~A}-1 \mathrm{P}-1$ & $60-61$ & 60.5 & - & - & 1865 & 25 \\
\hline CAMS \#150,118 & $4 \mathrm{~A}$ & 4A-1P-1 & $90-91$ & 90.5 & - & - & 1730 & 90 \\
\hline CAMS \#150,119 & $4 \mathrm{~A}$ & 4A-1P-1 & $148-149$ & 148.5 & - & - & 3170 & 25 \\
\hline CAMS \#150,120 & $4 \mathrm{~A}$ & $4 \mathrm{~A}-2 \mathrm{~B}-1$ & $14-15$ & 165.5 & - & - & 3035 & 35 \\
\hline CAMS \#177,920 & $4 \mathrm{~A}$ & $4 \mathrm{~A}-2 \mathrm{~B}-1$ & $42-43$ & 193.5 & - & - & 3550 & 35 \\
\hline CAMS \#147,318 & $4 \mathrm{~A}$ & $4 \mathrm{~A}-2 \mathrm{~B}-1$ & $80-81$ & 231.5 & - & - & 4555 & 30 \\
\hline CAMS \#147,319 & $4 \mathrm{~A}$ & 4A-3L-1 & $7-8$ & 265.5 & - & - & 4060 & 40 \\
\hline CAMS \#150,121 & $4 \mathrm{~B}$ & $4 \mathrm{~B}-2 \mathrm{~B}-1$ & $75-76$ & 141.5 & - & - & 4250 & 30 \\
\hline CAMS \#147,320 & $4 \mathrm{~B}$ & 4B-3L-1 & $18-19$ & 236.5 & - & - & 4655 & 30 \\
\hline CAMS \#147,321 & $4 \mathrm{~B}$ & 4B-3L-1 & $51-52.5$ & 269.5 & - & - & 4515 & 35 \\
\hline CAMS \#128,506 & UL-5 & UL-5 & $96-97$ & 96.5 & - & - & 2820 & 35 \\
\hline CAMS \#128,505 & UL-5 & UL-5 & $125-126$ & 125.5 & - & - & 3650 & 50 \\
\hline CAMS \#128,504 & UL-5 & UL-5 & $178-179$ & 178.5 & - & - & 4410 & 35 \\
\hline CAMS \#128,503 & UL-5 & UL-5 & 199-200 & 199.5 & - & - & 4000 & 35 \\
\hline
\end{tabular}

* Only ${ }^{210} \mathrm{~Pb}$ data below $6 \mathrm{~cm}$ was used to determine accumulation rate

$\dagger$ Value excluded from Bacon age model. Italics represent age inversions

because the ${ }^{210} \mathrm{~Pb}_{\text {excess }}$ accretion rate above $30 \mathrm{~cm}$ and core stratigraphy at $35 \mathrm{~cm}$ indicate this radiocarbon sample was not in its original stratigraphic position.

Foraminifera assemblages

Foraminifera were visually identified from 30-mg sediment aliquots, dry sieved to $125 \mu \mathrm{m}$ (Table 3). Foraminifera between 63 and $125 \mu \mathrm{m}$ were commonly covered in calcareous precipitates, which could not be dislodged with sieving or sonicating, rendering identification inconsistent or impossible, and hence were excluded. Each species was counted until at least 300 individuals (living or dead) were obtained. Counts were used to calculate relative abundance, and sediment aliquots were weighed to determine absolute abundance (individuals $\mathrm{mg}^{-1}$ of sediment) to address the different volumes of sample used (Schönfeld et al. 2012). This method was applied to coretop samples and core 4A downcore samples. We define "coretop" as the upper $5 \mathrm{~cm}$ intervals of sediment, which we assumed were mixed, as inferred from ${ }^{210} \mathrm{~Pb}$ profiles (Fig. 3). In core UL-5, foraminifera counts were performed on the $>250-\mu \mathrm{m}$ fraction. This size fraction was chosen because of the common occurrence of large benthic foraminifera along the Yucatan Peninsula coast (Martinez et al. 2018) and at this site. Data from core UL-5 (Electronic Supplementary Material [ESM]) were not collected at high resolution and were only used to corroborate the trends observed in core $4 \mathrm{~A}$. 


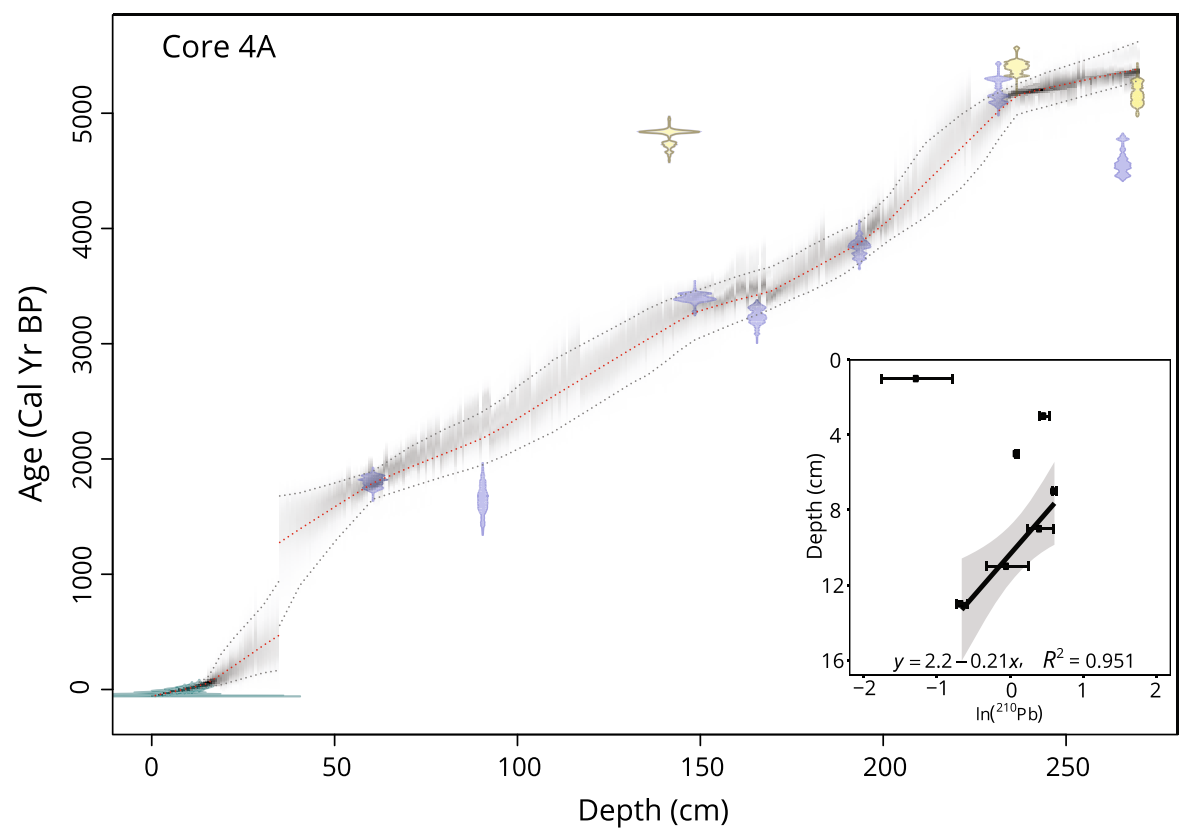

Fig. 3 Age-depth model for site 4A cores using radiocarbon dates from $4 \mathrm{~A}$ (blue) and $4 \mathrm{~B}$ (light yellow) and ${ }^{210} \mathrm{~Pb}$ accretion-derived age from site $5 \mathrm{~A}$ core (green, accretion rate from inset). Data is presented in Table 2. Gray dotted lines are the $95 \%$ confidence interval for ages. Offset at depth $35 \mathrm{~cm}$ represents an inferred erosional event (Fig. 2) removing

Carbon isotope analysis

Organic matter $\delta^{13} \mathrm{C}$ and $\mathrm{C}: \mathrm{N}$ mass ratios were analyzed simultaneously using a Carlo Erba 1108 elemental analyzer connected to a ThermoFinnigan Delta Plus XP isotope ratio mass spectrometer. A 2-mg sample from each sediment interval was acidified repeatedly using chilled $6 \%$ sulphurous acid, following Verardo et al. (1990), with an added sonication between acidifications to promote complete decarbonation. This method minimized effervescence and sample loss in sediments containing $95 \%$ carbonate mud (i.e., all samples in this study, excluding peat). Values are reported in reference to VPDB with instrumental reproducibility of $\delta{ }^{13} \mathrm{C}=0.2 \%$ (UC Santa Cruz Stable Isotope Lab). The C:N mass ratio is reported as dry weight \% organic $\mathrm{C}$ to dry weight $\%$ total $\mathrm{N}$, with a reproducibility of 0.1 .
800 years of sediment for site $4 \mathrm{~A}$. Inset ${ }^{210} \mathrm{~Pb}$-derived sediment accumulation rate calculated as $-0.0311 /-0.21=0.146 \mathrm{~cm} \mathrm{yr}^{-1} \sim$ $1.5 \mathrm{~mm} \mathrm{yr}^{-1}$ which is consistent with accretion rates determined for the northern lagoon (Gonneea et al. 2004). More detail on the age-depth models can be found in ESM

\section{Statistical analyses}

All statistical analyses were performed in R software (v. 3.5.0) (R Core Team 2020) with packages vegan (v. 2.5.2) (Oksanen et al. 2019) and rioja (v. 0.9.21) (Juggins 2017). Species richness (S), Shannon diversity $(\mathrm{H})$, and evenness $(\mathrm{E})$ were determined from equations presented in Buzas and Hayek (1998). Wisconsin double standardization was applied to raw abundance counts to maximize influence of rare species, and Q-mode and R-mode agglomerative clustering were performed using the Bray-Curtis dissimilarity matrix and Ward's linkage method (Sen Gupta 1999). Foraminifera assemblage names were assigned based on R-mode results, and depth intervals of assemblage occurrence were assigned based on Q-mode results. Cluster cophenetic correlation coefficient, which describes data distortion in cluster dendrograms, was determined using Pearson's correlation between the Bray-Curtis dissimilarity matrix and cluster cophenetic matrix (Davis 2002). Nonmetric multidimensional scaling (NMDS) was performed using the Bray-Curtis dissimilarity matrix of 
Table 3 Foraminifera species and modern environment

\begin{tabular}{|c|c|c|}
\hline Species & General salinity tolerance (psu) and environment & Reference \\
\hline $\begin{array}{l}\text { Ammonia } \\
\text { parkinsoniana }\end{array}$ & $\begin{array}{l}\text { Infaunal, euryhaline, } 4-41 \mathrm{psu} \text {, silty sand to calcareous mud, estuaries with } \\
\text { variable sedimentation and high organics, protected mangrove lagoons }\end{array}$ & $\begin{array}{l}\text { Murray (1991, 2006), Hayward } \\
\text { et al. (2004), Poag (2015) }\end{array}$ \\
\hline Ammonia tepida & Same as $A$. parkinsoniana, more sensitive to salinity variability & Poag (2015) \\
\hline $\begin{array}{l}\text { Ammonia } \\
\quad \text { pauciloculata }\end{array}$ & Infaunal, euryhaline, rare along Texas inner shelf estuaries & Poag (2015) \\
\hline $\begin{array}{l}\text { Ammotium sp. or } \\
\text { Ammobaculites } \\
\text { sp. }\end{array}$ & Infaunal, 4-41psu, silty mud, intertidal mudflats & Murray $(1991,2006)$ \\
\hline Archaias angulatus & $\begin{array}{l}\text { Epifaunal, epiphytic, } 34-37 \mathrm{psu} \text {, carbonate-rich sediments with seagrasses } \\
\text { (Thalassia sp.), shallow warm marginal marine }\end{array}$ & $\begin{array}{l}\text { Murray }(1991,2006), \text { Poag }(2015) \text {, } \\
\text { Sen Gupta (1999), Javaux and } \\
\text { Scott (2003) }\end{array}$ \\
\hline Borelis pulchra & $\begin{array}{l}\text { Epifaunal, epiphytic, } 35 \mathrm{psu} \text {, macroalgal substrates, back-reef lagoons and } \\
\text { tropical seagrass beds }\end{array}$ & $\begin{array}{l}\text { Javaux and Scott (2003), Poag } \\
\text { (2015), Murray (2006) }\end{array}$ \\
\hline Brizalina sp. & Infaunal, 31-35psu, tolerates dysoxia, marine inner/outer shelf & Murray $(1991,2006)$ \\
\hline $\begin{array}{r}\text { Cornuspira } \\
\text { involvens }\end{array}$ & $\begin{array}{l}\text { Epiphytic, seagrass beds, widespread inner shelf, nearshore marine } \\
\text { lagoons }\end{array}$ & Murray (2006) \\
\hline $\begin{array}{l}\text { Elphidium } \\
\text { discoidale }\end{array}$ & $35-37 \mathrm{psu}$, clastic sediments, warm water bays and estuaries & Poag (2015), Sen Gupta (1999) \\
\hline $\begin{array}{l}\text { Elphidium } \\
\text { galvestonense }\end{array}$ & Epifaunal, epiphytic, marshes, lagoons, and estuaries & Murray (2006); Poag (2015) \\
\hline Elphidium gunteri & Euryhaline, $25-31 \mathrm{psu}$, sandy mud, common to marshes, lagoons, estuaries & Murray $(1991,2006)$, Poag (2015) \\
\hline Elphidium lanieri & Protected nearshore lagoons and back-reefs & $\begin{array}{l}\text { Javaux and Scott (2003), Poag } \\
\quad \text { (2015) }\end{array}$ \\
\hline $\begin{array}{l}\text { Elphidium } \\
\text { poeyanum }\end{array}$ & $\begin{array}{l}\text { Epifaunal, euryhaline, 35-81psu, warm-temperate silty lagoons and } \\
\text { estuaries }\end{array}$ & $\begin{array}{l}\text { Murray }(1991,2006), \text { Sen Gupta } \\
\quad \text { (1999) }\end{array}$ \\
\hline $\begin{array}{l}\text { Hanzawaia } \\
\text { concentrica }\end{array}$ & Epifaunal, 34-36psu, warm marine inner shelf, bays, estuaries & $\begin{array}{l}\text { Sen Gupta (1999), Poag (2015), } \\
\quad \text { Murray }(19,912,006)\end{array}$ \\
\hline $\begin{array}{l}\text { Haynesina } \\
\text { germanica }\end{array}$ & $\begin{array}{l}\text { Infaunal, common to salt marshes and estuaries with variable mud and } \\
\text { organics }\end{array}$ & Murray (2006); Poag (2015) \\
\hline $\begin{array}{l}\text { Laevipeneroplis } \\
\quad \text { proteus }\end{array}$ & $\begin{array}{l}\text { Epifaunal, epiphytic, } 35 \mathrm{psu} \text {, warm carbonate-rich lagoon seagrass and } \\
\text { macroalgae beds in lagoons and innermost shelf }\end{array}$ & $\begin{array}{l}\text { Murray (2006), Poag (2015), Sen } \\
\text { Gupta (1999) }\end{array}$ \\
\hline Miliammina fusca & Epifuanal, euryhaline, 7-19psu, silty mud, shallow lagoons and estuaries & Murray (2006) \\
\hline \multicolumn{3}{|l|}{ Quinqueloculina } \\
\hline Bicarinata & $\begin{array}{l}\text { Epifaunal, carbonate-rich brackish-marine bays, lagoons, inner shelf, } \\
\text { commonly near seagrass beds }\end{array}$ & $\begin{array}{l}\text { Javaux and Scott (2003), Poag } \\
\text { (2015), Murray (1991, 2006), } \\
\text { Sen Gupta (1999) }\end{array}$ \\
\hline \multicolumn{3}{|l|}{ Quinqueloculina } \\
\hline Laevigata & $\begin{array}{l}\text { Epifaunal, } 10-47 \mathrm{psu} \text {, seagrasses and algae beds, common to mangroves of } \\
\text { the Caribbean }\end{array}$ & $\begin{array}{l}\text { Murray (2006), Javaux and Scott } \\
\text { (2003), Sen Gupta (1999), }\end{array}$ \\
\hline $\begin{array}{l}\text { Quinqueloculina } \\
\text { linneiana }\end{array}$ & Epifaunal, nearshore bays and lagoons similar to $Q$. bicarinata & Poag (2015) \\
\hline Rosalina sp. & $\begin{array}{l}\text { Epifuanal, clinging to seagrasses, warm marine lagoons, mangroves, and } \\
\text { back-reef }\end{array}$ & $\begin{array}{l}\text { Murray (2006), Poag (2015), Sen } \\
\text { Gupta (1999), Javaux and Scott } \\
\text { (2003) }\end{array}$ \\
\hline $\begin{array}{l}\text { Trichohyalus } \\
\text { aguayoi }\end{array}$ & $\begin{array}{l}\text { Epifaunal, brackish salinity, characteristic of landlocked mangrove ponds, } \\
\text { common to Bermuda and brackish restricted lagoons of Florida, } \\
\text { Bahamas, Cuba, and Belize }\end{array}$ & $\begin{array}{l}\text { Javaux and Scott (2003), Murray } \\
\text { (2006) }\end{array}$ \\
\hline Triloculina sp. & Likely similar to $\mathrm{T}$ trigonula, $35-81 \mathrm{psu}$ & Murray $(1991,2006)$ \\
\hline $\begin{array}{l}\text { Triloculina } \\
\quad \text { linneiana }\end{array}$ & carbonate-rich mud, nearshore marine lagoons and mangroves & $\begin{array}{l}\text { Javaux and Scott (2003), Murray } \\
\text { (2006) }\end{array}$ \\
\hline
\end{tabular}


Table 3 continued

\begin{tabular}{llc}
\hline Species & General salinity tolerance (psu) and environment & Reference \\
\hline $\begin{array}{c}\text { Triloculina } \\
\text { trigonula }\end{array}$ & $\begin{array}{c}\text { Epifaunal, clinging to vegetation, marine to hypersaline, carbonate-rich } \\
\text { inner shelf, low tidal marsh, and nearshore mangrove }\end{array}$ & $\begin{array}{c}\text { Poag (2015), Murray (2006), Sen } \\
\text { Gupta (1999), Javaux and Scott } \\
\text { (2003) }\end{array}$ \\
$\begin{array}{c}\text { Trochammina } \\
\text { macrascens }\end{array}$ & $\begin{array}{c}\text { Epifaunal, clinging to vegetation, organic-rich mud, common to mid, high Javaux and Scott (2003), Murray } \\
\text { marsh and mangroves }\end{array}$ & $(1991,2006)$ \\
\hline
\end{tabular}

Visual identification from Javaux and Scott (2003) and Poag (2015), and environments from remaining listed references

the Wisconsin standardized data with $k=3$ dimensions. Continuous variables were natural logtransformed for plotting as vectors.

PERMANOVA and beta-dispersion statistical tests were performed to determine significant differences between cluster centroids and between cluster spreads, respectively (Anderson 2001; Anderson et al. 2006). To check significant difference between centroid positions determined from PERMANOVA -which gives a significant result for centroid position or variance-a randomized resampling was performed to simulate a $p$ value for centroid position alone. Clusters were pooled, randomly sampled without replacement, plotted with NMDS ordination, and distance was measured between NMDS centroids of the randomized clusters. A total of 10,000 iterations were performed and compared to the original centroid distance. Kendall correlation was performed for non-normally distributed continuous variables.

\section{Results}

Modern salinity gradient

Lagoon water salinity increases from a minimum of $14 \mathrm{psu}$ in the northern lagoon (with variability near springs) to $33 \mathrm{psu}$ in the southern lagoon, close to the ocean (Table 1). Based on observations in the field, wave energy is lower in the northern interior region (more protected) than in the southern region, close to the coastline.

\section{Sedimentology}

Core 4A provided the longest sediment record (262 cm, Fig. 2), hence most analyses were performed on core 4A. The stratigraphy consists of a basal peat layer from 262 to $230 \mathrm{~cm}$, with a transition from $230-228 \mathrm{~cm}$ to massive carbonate mud that persist from 228 to $0 \mathrm{~cm}$, with increasing light brown pigmentation upcore (Fig. 2). Fossil bivalves, gastropods, foraminifera, and fragments thereof are rare in peat and common in carbonate mud. Pieces of charcoal and organic matter $<1 \mathrm{~mm}$ occur occasionally in the carbonate mud. Interval $210-170 \mathrm{~cm}$ contains more gastropods than other calcareous microfossils, and interval $170-140 \mathrm{~cm}$ contains more carbonate mud with light brown pigmentation and frequent occurrence of gastropods, ostracods, and foraminifera. From 140 to $112 \mathrm{~cm}$, coarse-grained material (1-cm clams) and carbonate mud predominate, and bivalves disappear above $112 \mathrm{~cm}$. Interval $112-0 \mathrm{~cm}$ is characterized by carbonate mud, frequent gastropods, and abundant foraminifera. From 36 to $34 \mathrm{~cm}$ a coarse $(0.5-1.0 \mathrm{~mm})$ layer of foraminifera and gastropods occurs, with a notable color transition from light brown to reddish brown (Fig. 2b). Core 4B exhibits nearly identical stratigraphy (Fig. 2a) and consists of a basal peat layer overlain by massive carbonate mud and fossil bivalves, gastropods, and foraminifera from 230 to $0 \mathrm{~cm}$, with a coarse layer of gastropods and foraminifera from 36 to $34 \mathrm{~cm}$ (Fig. 2b). Wet bulk density values are similar between the two cores, with $1.3 \mathrm{~g} / \mathrm{mL}$ in the peat layer, a maximum of $1.9 \mathrm{~g} / \mathrm{mL}$ just above the peat-mud transition $(229 \mathrm{~cm})$, and a trend to $1.4 \mathrm{~g} / \mathrm{mL}$ at the surface (Fig. 2a). Based on stratigraphy, wet sediment density, and core 
proximity, we are confident that identical depths in the $4 \mathrm{~A}$ and $4 \mathrm{~B}$ cores represent the same strata.

The coarse-grained layer centered on $35 \mathrm{~cm}$ in cores $4 \mathrm{~A}$ and $4 \mathrm{~B}$ is also observed in cores $2 \mathrm{~A}$ (31$29 \mathrm{~cm}), 8 \mathrm{~A}(35-31 \mathrm{~cm})$, and $6 \mathrm{~A}(33-28 \mathrm{~cm})$, but was not observed in core 7A (Fig. 2b). The layer is thickest $(5 \mathrm{~cm})$ in southern lagoon core $6 \mathrm{~A}$ and thinnest $(2 \mathrm{~cm})$ in the northern lagoon. The remaining short cores (Table 1) were not sampled below $30 \mathrm{~cm}$ depth.

Radioisotope activities and age-depth models

${ }^{210} \mathrm{~Pb}$ activity in the $0-5 \mathrm{~cm}$ interval of short push core 5-SPC from site 5A reflected bioturbation and mixing (Table 2), and was thus excluded from accretion rate calculations. ${ }^{210} \mathrm{~Pb}$ activity in the interval $6-13 \mathrm{~cm}$ yielded an accretion rate of $1.5 \pm$ $0.2 \mathrm{~mm} \mathrm{y}^{-1}$ (Fig. 3 inset). Radiocarbon data for cores 4A and 4B showed the expected increase in age with depth, although there are four age inversions (Table 2). Three ${ }^{14} \mathrm{C}$ age inversions were observed in core $4 \mathrm{~A}$ from $4 \mathrm{~A}-3 \mathrm{~L}-1265.5 \mathrm{~cm}$ to $4 \mathrm{~A}-2 \mathrm{~B}-1$ $80.5 \mathrm{~cm}\left(495{ }^{14} \mathrm{C}\right.$ years $), 4 \mathrm{~A}-2 \mathrm{~B}-1193.5 \mathrm{~cm}$ to $4 \mathrm{~A}-$ $1 \mathrm{P}-1148.5 \mathrm{~cm}\left(135{ }^{14} \mathrm{C}\right.$ years $)$, and $4 \mathrm{~A}-1 \mathrm{P}-190.5 \mathrm{~cm}$ to $60.5 \mathrm{~cm}\left(135{ }^{14} \mathrm{C}\right.$ years $\left.)\right)$. One inversion occurs in core 4B from 4B-3L-1 269.5 to $236.5\left(140{ }^{14} \mathrm{C}\right.$ years), and one in UL-5 (ESM). The mean ${ }^{14} \mathrm{C}$ age inversion $(n=5)$ is 263 uncalibrated years across a mean sediment interval of $27 \pm 7 \mathrm{~cm}$.

The Bayesian age-depth model for core 4A (Fig. 3) implies a long-term mean linear sediment accumulation rate between 0.4 and $0.6 \mathrm{~mm} \mathrm{y}^{-1}$. Assuming the lagoon-wide coarse sediment layer at $35 \mathrm{~cm}$ depth (Fig. 2b) is an erosional event, the age model for core 4A indicates a missing time span of 800 years, from 1300 to 500 calendar years Before Present (hereafter BP). A comparison of age models with and without the erosional event and ${ }^{210} \mathrm{~Pb}_{\text {excess }}$ data can be found in ESM. The model with an erosional event and with ${ }^{210} \mathrm{~Pb}_{\text {excess }}$ accretion rates, though complex, better reconciles radioisotope and sedimentological observations and more accurately reflects age model uncertainty for this dynamic coastal site than does a simpler radiocarbon model.
Benthic foraminifera identification and distribution

More than 27,000 foraminifera were counted in 90 samples, and 26 species were identified (Table 3). Foraminifera appeared pristine, with no pitting or dissolution noted in coretop or downcore specimens.

For all modern and fossil samples, the dominant species were Ammonia parkinsoniana (34.7\%), Quinqueloculina laevigata (14.8\%), Elphidium gunteri (14.1\%), Elphidium poeyanum (11.7\%), Triloculina trigonula (6.5\%), Agglutinated taxa (6.0\%), Trichohyalus aguayoi (3.7\%), Elphidium galvestonense (2.7\%), Ammonia tepida (1.3\%), and Haynesina germanica (1.1\%), which comprise $96.6 \%$ of all individuals observed. Mean absolute abundance for all taxa is 11.9 individuals per $\mathrm{mg}$ sediment (ind $\mathrm{mg}^{-1}$ ), with the highest absolute abundances among A. parkinsoniana $\left(4.1\right.$ ind $\left.\mathrm{mg}^{-1}\right)$, Q. laevigata $(1.8$ ind $\left.\mathrm{mg}^{-1}\right)$, E. gunteri (1.7 ind $\left.\mathrm{mg}^{-1}\right)$, E. poeyanum $(1.3$ ind $\mathrm{mg}^{-1}$ ). Remaining taxa absolute abundances are $<1$ ind $\mathrm{mg}^{-1}$.

The relative abundances of fossil taxa in core 4A (Fig. 4a) are A. parkinsoniana (41.4\%), E. poeyanum (13.0\%), E. gunteri (11.9\%), Q. laevigata (8.6\%), T. aguayoi $(6.5 \%)$, agglutinated taxa $(5.6 \%)$, E. galvestonense (4.6\%), T. trigonula (2.8\%). Other taxa included Borelis pulchra, Trochammina macrascens, and unknown taxa (1.2\%), and Quinqueloculina linneiana (1\%). Together, these taxa comprise $96.7 \%$ of individuals observed in core 4A. Total absolute abundance is 9.7 ind $\mathrm{mg}^{-1}$, dominated by $A$. parkinsoniana (4.0 ind $\left.\mathrm{mg}^{-1}\right)$, E. poeyanum (1.3 ind $\mathrm{mg}^{-1}$ ), and $E$. gunteri (1.2 ind $\mathrm{mg}^{-1}$ ), with remaining taxa $<1$ ind $\mathrm{mg}^{-1}$. T. aguayoi was observed only in the interval 262-229 cm (5300-4900 BP), Laevipeneroplis proteus and Archaias angulatus were observed only in the interval 229-227 cm (4900-4800 BP), and other taxa were distributed from 227 to $0 \mathrm{~cm}(4800$ $\mathrm{BP}$ - present).

The relative abundance of taxa in modern coretop samples (Fig. 4b) was A. parkinsoniana (25.7\%), $Q$. laevigata (23.0\%), E. gunteri (17.0\%), T. trigonula (11.4\%), E. poeyanum (9.9\%), agglutinated taxa (6.4\%), H. germanica (2.1\%), and A. tepida (1.9\%), which comprise $97.7 \%$ of individuals observed in coretop samples. Absolute abundance for all coretop taxa was 16.8 ind $\mathrm{mg}^{-1}$ sediment, distributed as $A$. parkinsoniana (4.4 ind $\mathrm{mg}^{-1}$ ), Q. laevigata (3.9 ind 
$\left.\mathrm{mg}^{-1}\right)$, E. gunteri (2.9 ind $\left.\mathrm{mg}^{-1}\right)$, T. trigonula (1.9 ind $\left.\mathrm{mg}^{-1}\right)$, E. poeyanum (1.7 ind $\left.\mathrm{mg}^{-1}\right)$, agglutinated taxa (1.1 ind $\left.\mathrm{mg}^{-1}\right), H$. germanica $\left(0.4\right.$ ind $\left.\mathrm{mg}^{-1}\right)$, and $A$. tepida $\left(0.3\right.$ ind $\left.\mathrm{mg}^{-1}\right)$, with all other taxa $\leq 0.1$ ind $\mathrm{mg}^{-1}$. E. lanieri, T. aguayoi, L. proteus, and $A$. angulatus were not observed in any coretop sample.

Stable carbon isotopes of organic matter

The core 4A peat, in the interval 262-229 cm (5300$4900 \mathrm{BP})$, is characterized by mean $\delta^{13} \mathrm{C}_{\text {org }}=$ $-27.96 \%$ and mean $\mathrm{C}: \mathrm{N}=23.8$. At $227 \mathrm{~cm}(4800$ $\mathrm{BP})$ in the carbonate mud, $\delta^{13} \mathrm{C}_{\mathrm{org}}=-19.27 \%$ and $\mathrm{C}$ : $\mathrm{N}=8.6$. From 227 to 135 (4800-3000 BP) mean $\delta^{13} \mathrm{C}_{\text {org }}=-19.90 \%$ and $\mathrm{C}: \mathrm{N}=8.3$, and from $135-0 \mathrm{~cm}$ (3000 BP - Present), $\delta{ }^{13} \mathrm{C}_{\text {org }}$ changes from $-19.90 \%$ o to $-24.04 \%$ and $\mathrm{C}: \mathrm{N}$ changes from 8.3 to 8.9 (Fig. 4a). In the modern lagoon, values of $\delta^{13} \mathrm{C}_{\mathrm{org}}$ and $\mathrm{C}: \mathrm{N}$ ratios are $-23.74 \%$ and 8.8 , respectively, in the northern lagoon and $-20.89 \%$ and 11.5 in the southern lagoon (Fig. 4b).

Diversity, clustering, and statistical relationships

R-mode cluster analysis of fossil and modern foraminifera indicates five clusters of commonly cooccurring taxa with a cophenetic correlation coefficient of 0.72 (Fig. 5a). We refer to these clusters by simplified assemblage names, which are BolivinaHanzawaia-Rosalina, Trichohyalus, Archaias-Laevipeneroplis, Ammonia-Elphidium, and AgglutinatedHaynesina. All five assemblages were observed in core 4A, whereas assemblages Archaias-Laevipeneroplis and Trichohyalus were absent from modern coretop sediments.

Q-mode unconstrained cluster analysis of core 4A resulted in four common clusters with a cophenetic correlation coefficient of 0.71 (Fig. 5b). In Fig. 4, clusters are colored shades of gray and describe dominant assemblages at the following depth intervals: Cluster IV occurs from 262 to $240 \mathrm{~cm}$ (53305150 BP) and is characterized by the Trichohyalus and Ammonia-Elphidium assemblages, with foraminifera distribution of T. aguayoi (57\%), Borelis pulchra and Other taxa (10\%), E. poeyanum (10\%, A. parkinsoniana (9\%), T. trigonula (7\%), Q. laevigata (4\%), A. tepida (2\%), and $<1 \%$ of E. gunteri, $Q$. linneiana, and agglutinated taxa. Cluster III occurs from 210 to $170 \mathrm{~cm}(4550-3400 \mathrm{BP})$ and is characterized by both the Ammonia-Elphidium and Bolivina-Hanzawaia-Rosalina assemblages, with a taxa distribution of E. poeyanum (41\%), A. parkinsoniana (21\%), T. trigonula (10\%), Q. linneiana (7\%), E. gunteri (4\%), Q. laevigata (4\%), Bolivina sp. (4\%), Triloculina sp. (3\%), E. galvestonense (1\%), and rare occurrence of other taxa including $C$. involvens and Rosalina sp. Cluster II is most prominent from 160 to $65 \mathrm{~cm}(3400-1850 \mathrm{BP})$ and is characterized by the Ammonia-Elphidium assemblage, with A. parkinsoniana (58\%), E. gunteri (17\%), E. poeyanum (9\%), E. galvestonense (8\%), agglutinated taxa $(2.5 \%), Q$. laevigata $(2 \%), T$. trigonula (1\%), and $<3 \%$ other taxa. Cluster II includes the Agglutinated-Haynesina assemblage ca. 1900 BP. Cluster I contains samples from 60 to $0 \mathrm{~cm}$ (1700 BP-Present) and is characterized by the Agglutinated-Haynesina assemblage.

Q-mode cluster analysis of coretop samples (Fig. 5c) indicates two sample clusters with a cophenetic correlation coefficient of 0.64 . Cluster 1 occurs in the northern lagoon from 0 to $11.5 \mathrm{~km}$ along the lagoon (Fig. 4b) and is characterized by the Agglutinated-Haynesina assemblage, and includes Quinqueloculina laevigata (38\%), Ammonia parkinsoniana (19\%), agglutinated Ammotium sp. and Miliammina fusca (12\%), Elphidium gunteri (11\%), E. poeyanum (10\%), low abundances of Triloculina $(<5 \%)$, and rare occurrences of Haynesina and other species. Cluster 2 occurs in the southern lagoon from 11.5 to $17.5 \mathrm{~km}$ (Fig. 4b), is characterized by the Bolivina-Hanzawaia-Rosalina assemblage, and includes A. parkinsoniana (34\%), E. gunteri (23\%), T. trigonula (20\%), E. poeyanum (10\%), Q. laevigata (7\%), and the presence of taxa not found in Cluster 1, including Hanzawaia concentrica, Rosalina sp., Cornuspira involvens, Bolivina sp., E. galvestonense, E. discoidale and Borelis pulchra (grouped in Other).

Diversity indices $\mathrm{S}, \mathrm{H}$, and $\mathrm{E}$ change with the faunal succession upcore in 4A (Fig. 4a). From Phases 1 to 4 (dashed lines in Fig. 4a), respective mean $\mathrm{S}$ changed from $8.8-11.8$ to $8.9-7.6$, mean $\mathrm{H}$ from 1.05-1.31 to 0.44-0.52, and mean E from 0.360.34 to $0.44-0.52$. A maximum $S$ of 18 occurs at $229 \mathrm{~cm}(4900 \mathrm{BP})$ and a minimum of 6 occurs at $170 \mathrm{~cm}$ (3400 BP). Diversity $\mathrm{H}$ follows a similar trend, but remains high for the last $2900 \mathrm{BP}$, due to an increase in absolute abundance, and $\mathrm{E}$ increases over time. In modern samples, the northern lagoon has 


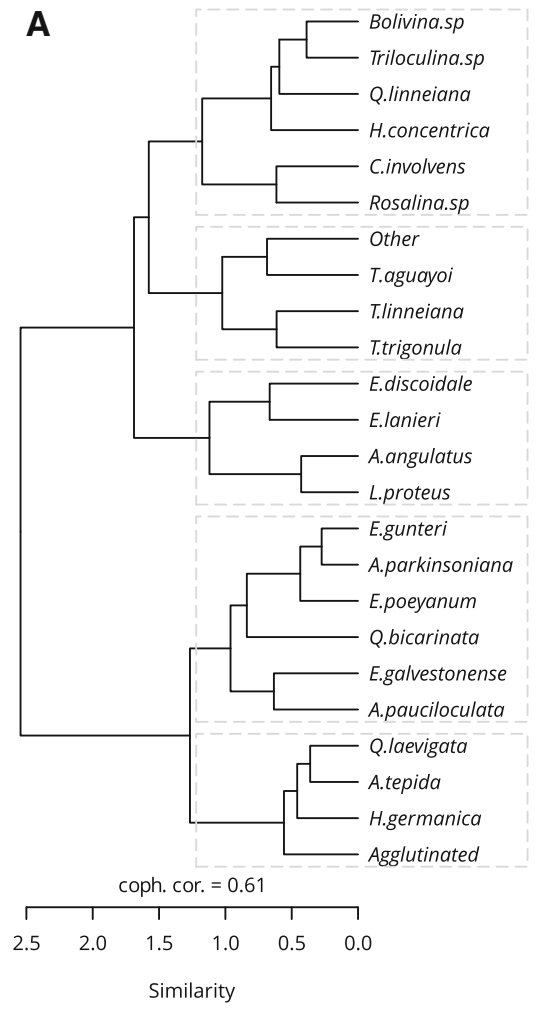

Fig. 4 A R-mode cluster analysis of all modern and fossil foraminifera observed. Gray dashed boxes encompass cooccurring taxa which are given assemblage names (from top to bottom): Bolivina-Hanzawaia-Rosalina, Trichohyalus, Archaias-Laevipeneroplis, Ammonia-Elphidium, and Agglutinated-

values of $\mathrm{S}=9, \mathrm{H}=1.64$, and $\mathrm{E}=0.57$, and the southern lagoon has values of $\mathrm{S}=11, \mathrm{H}=1.71$, and $\mathrm{E}=0.53$ (Fig. $4 \mathrm{~b}$ ).

NMDS of core 4A clusters and environmental vectors are presented in Fig. 6 and represent statistical relationships given in Table 4. All four clusters plot without overlap in ordination space (Fig. 6A), and foraminifera composition of each cluster is distinct and significantly different (Fig. 6C and Table 4, PERMANOVA Source: Cluster, $p=0.003$; Bootstrapping Source: Cluster, $p<<0.01$ ) with no significant difference in cluster dispersion (Beta dispersion Source: Cluster, $p=0.111)$. Bulk sediment $\delta^{13} \mathrm{C}_{\text {org }}$ and $\mathrm{C}: \mathrm{N}$ ratio significantly correlate with cluster composition ( $p=0.001$ for both). Significant correlation between $\delta^{13} \mathrm{C}_{\mathrm{org}}$ and $\mathrm{E}$ (Kendall $\tau=$ $-0.291, p=0.014$ ) and $S$ (Kendall $\tau=0.370, p=$ 0.003 ) also show a significant, but weak relationship. $\mathrm{S}$ and $\mathrm{H}$ showed no significant correlations, but plot

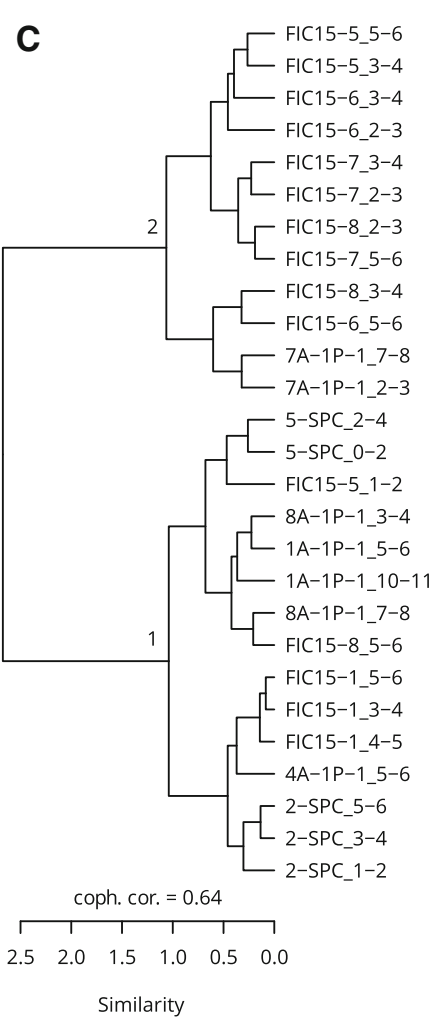

Haynesina. Taxa list given in Table 3. Q-mode cluster analysis and cophenetic correlation coefficients of $\mathbf{B}$ site $4 \mathrm{~A}$ and C coretop samples. Arabic and Roman numeral notations are the clusters colored in Figs. 4 and 6

as long vectors in the general direction of $\delta^{13} \mathrm{C}_{\text {org }}$ (Fig. 6a).

NMDS of modern coretop Clusters 1 and 2 show no overlap (Fig. 6b) and are significantly different in assemblage composition (Fig. 6d and Table 4, PERMANOVA Source: Cluster, $p=0.001$; Bootstrapping Source: Cluster, $p<<0.01$ ), but are not significantly different in the variance of species abundance (Beta dispersion Source: Cluster, $p=$ 0.128). The largest gradients (longest vectors) along the lagoon transect are $\delta^{13} \mathrm{C}_{\text {org }}, \mathrm{C}: \mathrm{N}$ ratio, and salinity (Fig. 6b). PERMANOVA results are significant for salinity, $\delta{ }^{13} \mathrm{C}_{\mathrm{org}}$, and cluster composition $(p=0.001$, Table 4$)$, and temperature is significant $(p=0.014)$. Species richness $(\mathrm{S}), \delta^{13} \mathrm{C}_{\mathrm{org}}$, and $\mathrm{C}: \mathrm{N}$ ratios are significantly correlated (Kendall correlation, $\tau=0$.460 and 0.46 , respectively, $p=0.002$ for both), but no significant correlation is observed between the $\delta^{13} \mathrm{C}_{\text {org }}$ and assemblage diversity $(\mathrm{H})$ or evenness (E). $\mathrm{S}$ is significantly correlated with distance along 
the transect from the northern to southern lagoon (Table 4), coincident with the observed decrease in lagoon wave energy from north to south. Results and figures related to auxiliary core UL-5 are described in the ESM.

\section{Discussion}

Modern environment in Celestun Lagoon

\section{Distributions of flora and fauna}

Foraminiferal and geochemical analyses in surface sediments and water along Celestun Lagoon reveal differences between the northern and southern lagoon regions. The Agglutinated-Haynesina assemblage occurs only in the northern lagoon, whereas the
Bolivina-Hanzawaia-Rosalina assemblage occurs only in the southern lagoon (Fig. 4b). The Ammonia-Elphidium assemblage is common in both regions. The Trichohyalus and Archaias-Laevipeneroplis assemblages were not observed in the modern lagoon. Maximum species richness (15) and diversity (1.96) both occur in the middle of the lagoon, about $13 \mathrm{~km}$ from the southern opening, where assemblages overlap (Fig. 4b) and the habitat transitions from a protected low-salinity lagoon to a higher-energy marine-influenced lagoon. The assemblage distribution aligns with gradients in salinity, temperature, $\delta^{13} \mathrm{C}$, and $\mathrm{C}: \mathrm{N}$ of $\mathrm{OM}$ (Fig. 6b). Strong association (clustering) of foraminifera assemblages with specific salinity and carbon isotope ranges suggests that the distribution of benthic foraminifera in Celestun Lagoon is controlled in part by salinity, vegetation, and, to a lesser extent, temperature. PERMANOVA

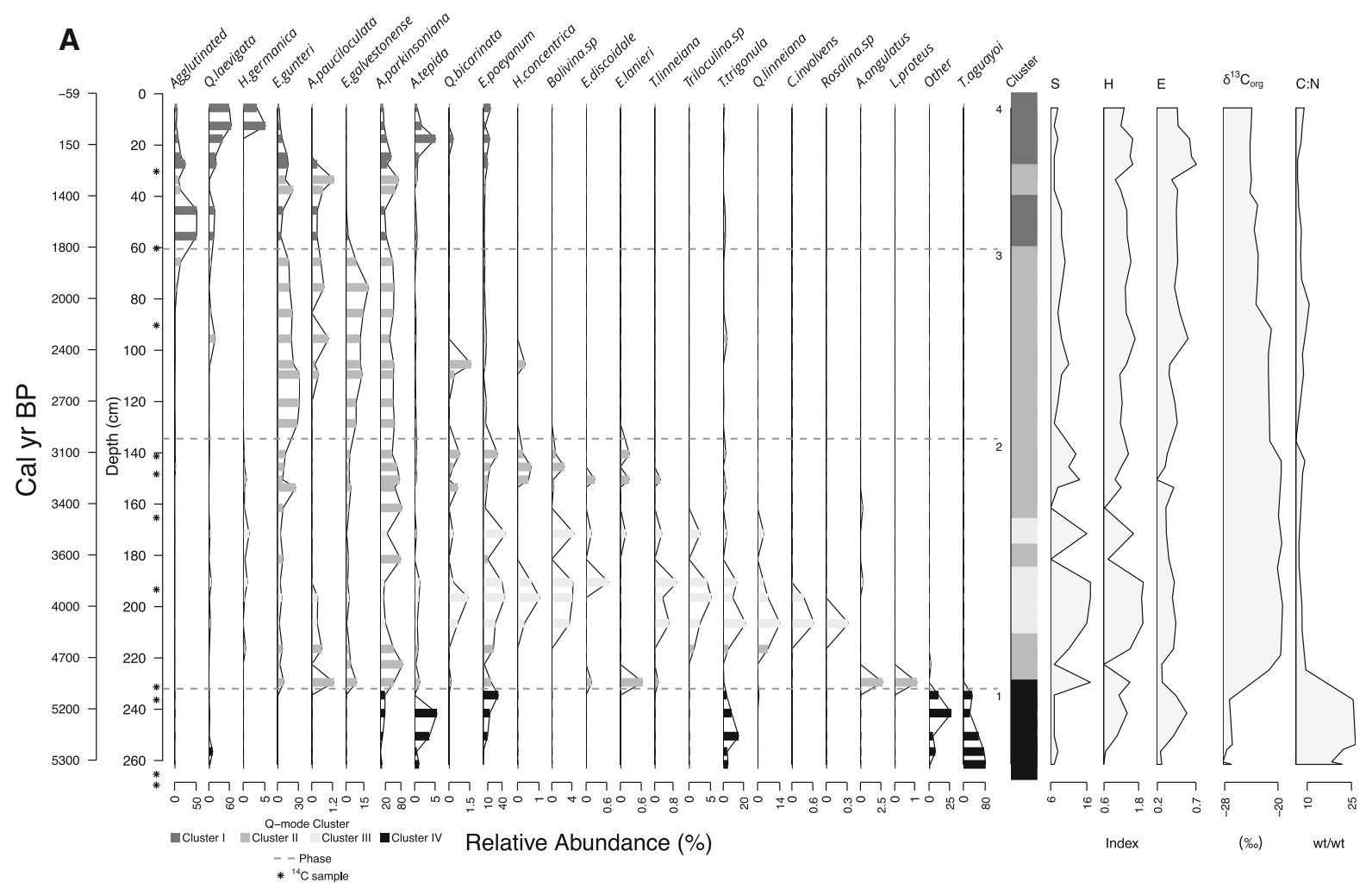

Fig. 5 Stratigraphic diagrams of benthic foraminifera colored by cluster results (from Fig. 5) and paired with diversity indices and bulk sediment organic carbon isotope data for $\mathbf{A}$ site $4 \mathrm{~A}$ cores, with an age scale obtained from Fig. 3, and $\mathbf{B}$ coretop samples from north to south in the lagoon (Fig. 1). Dashed lines represent stratigraphic transitions between assemblages. Note change in scale on the bottom axis of each panel and the age jump at $35 \mathrm{~cm}$ reflecting a missing time span from 1300 to 500 cal yr BP 


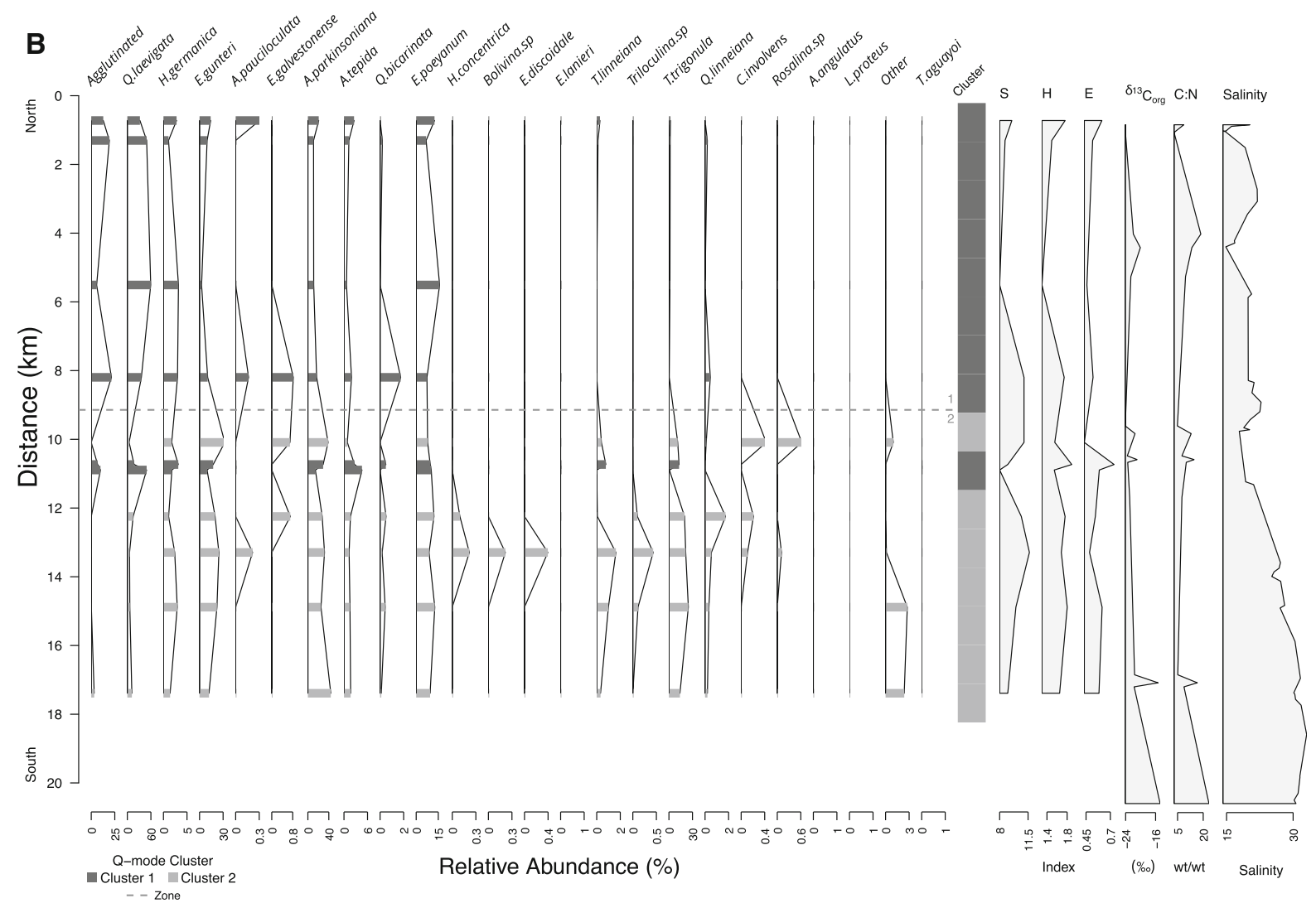

Fig. 5 continued

results support significant relationships among these variables (Table 4).

Clusters dominated by the Agglutinated-Haynesina assemblage represent brackish salinity and shallow lagoon mangroves, and clusters dominated by the Bolivina-Hanzawaia-Rosalina assemblage represent inner marine shelf and seagrass habitat, which are the environments in which species of these assemblages have been found around the Caribbean (Table 3). Low wave energy and muddy substrate in the enclosed northern lagoon also promote the abundance of agglutinated foraminifera like Miliammina fusca (Debenay and Guillou 2002). Lagoon water temperature is weakly correlated with cluster composition (Table 4, Fig. 6b), but does not exhibit large changes in mean temperature among sites sampled (29.2 士 $2.6{ }^{\circ} \mathrm{C}$, Table 1). Salinity exhibits the greatest variability in the lagoon. Although Trichohyalus and Archaias-Laevipeneroplis were not observed in modern Celestun, we infer their habitats based on modern occurrence at other sites in the Gulf of Mexico and Caribbean. Trichohyalus aguayoi occurs in inland mangrove ponds in Bermuda (Javaux and Scott 2003) and groundwater-flooded blue holes in the Bahamas (van Hengstum et al. 2020), and thus represents lowsalinity, isolated mangrove ponds with minimal ocean influence (Table 3). Archaias angulatus and Laevipeneroplis proteus (also known as Peneroplis proteus) inhabit marine seagrass of the genus Thalassia off the coasts of Belize and Florida (Hallock and Peebles 1993; Sen Gupta 1999). Thus, the Archaias-Laevipeneroplis assemblage represents marine-salinity, shallow-shelf environments with Thalassia seagrass vegetation (Table 3).

In the marine-brackish conditions of southern Celestun Lagoon, euryhaline Ammonia and Elphidium were found alongside epiphytic Quinqueloculina and Rosalina taxa, suggesting seagrass vegetation may contribute to assemblage diversity, but alone is insufficient in determining modern assemblage 


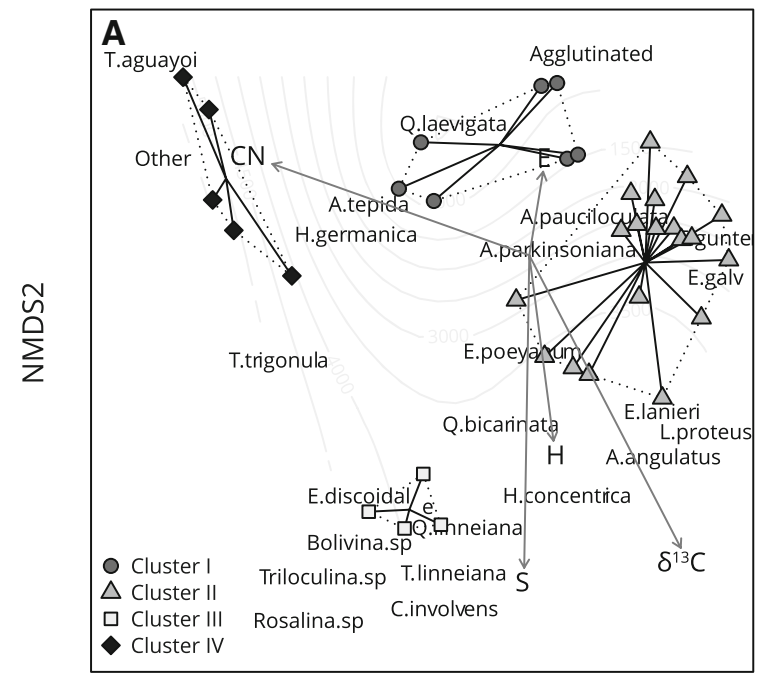

NMDS1

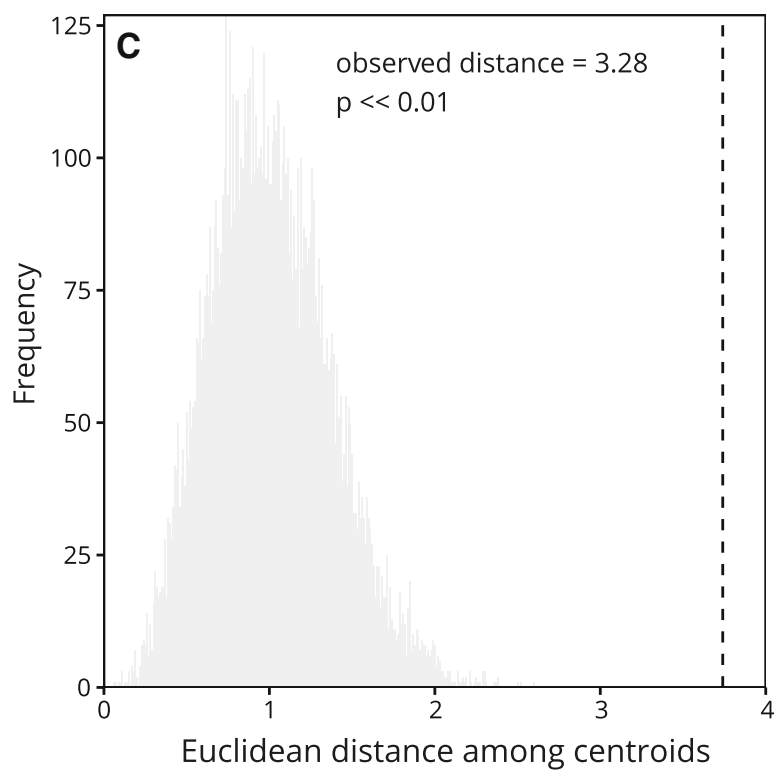

Fig. 6 NMDS result $(k=3)$ for $\mathbf{A}$ site $4 \mathrm{~A}$ cores (stress=0.082) with contours of age and $\mathbf{B}$ coretop samples (stress=0.094) with contours of distance. Vectors $\mathrm{S}, \mathrm{H}$, and $\mathrm{E}$ are indices of species count, Shannon diversity, and evenness, respectively, and $\delta^{13} \mathrm{C}$ and $\mathrm{C}: \mathrm{N}$ mass ratio are of bulk sediment organic matter. In $\mathrm{B}$, temp is temperature $\left({ }^{\circ} \mathrm{C}\right)$ and sal is salinity (psu) of the lagoon water column. Clusters are joined at their centroids and outlined by dotted lines, and distributions of

distribution. The importance of salinity is further demonstrated by benthic foraminifera observed $10 \mathrm{~km}$ south of Celestun Lagoon, in Isla Arena, which has similar sedimentology, geometry, and vegetation as Celestun, but higher salinity because

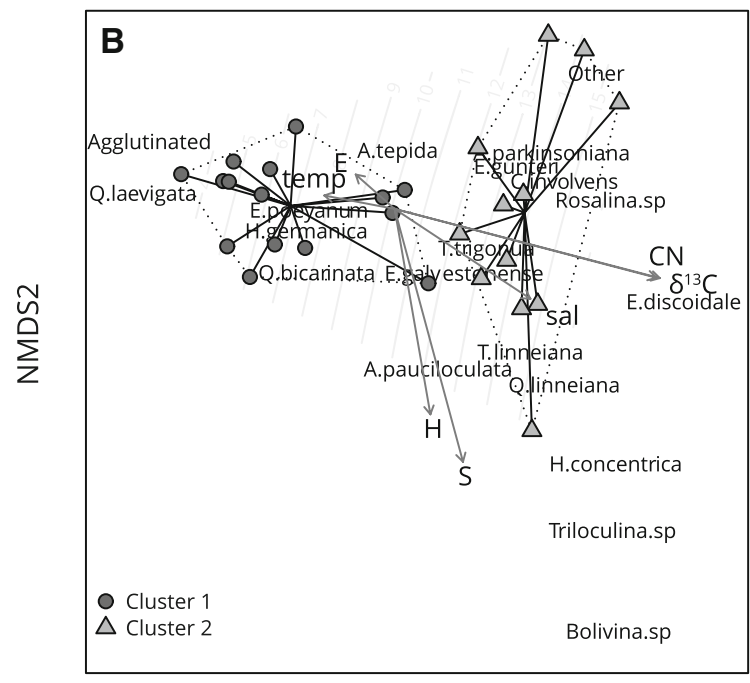

NMDS1

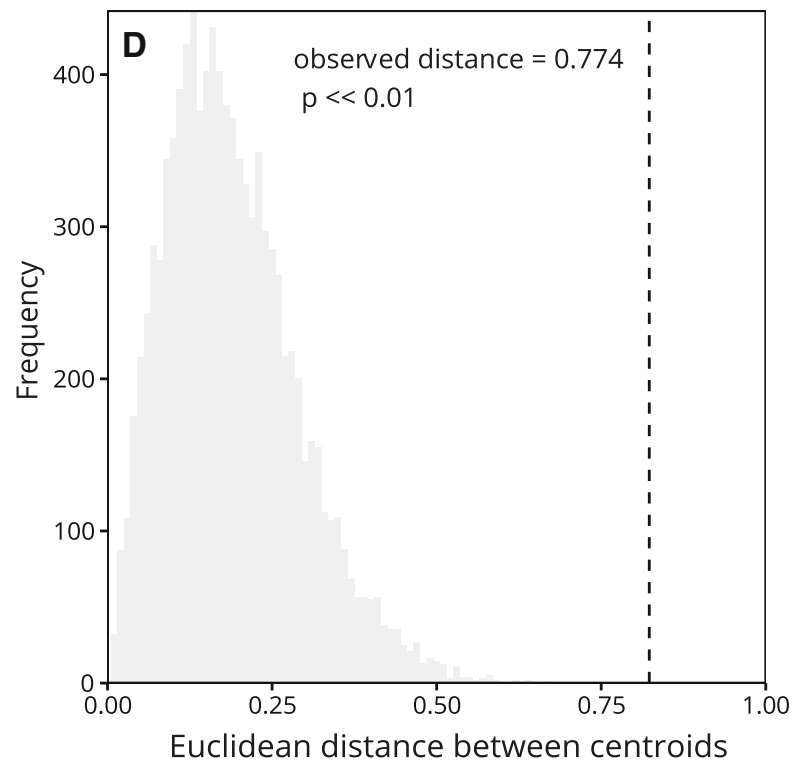

Euclidian distances among group centroids are given for $\mathbf{C}$ site 4A cores and $\mathbf{D}$ coretop samples and compared to observed centroid distance (dashed line). C and D represent simulated p-values for the null hypothesis that clusters (faunal distributions) are not significantly different from one another within each panel A and B. Note that absolute value of centroid distances is not meaningful, only the distribution relative to the observed distance

of greater seawater input (Lowery and Rankey 2017). As a result of this higher salinity, the Isla Arena assemblages are dominated by miliolid and peneroplid foraminifera that prefer near-marine salinity. 


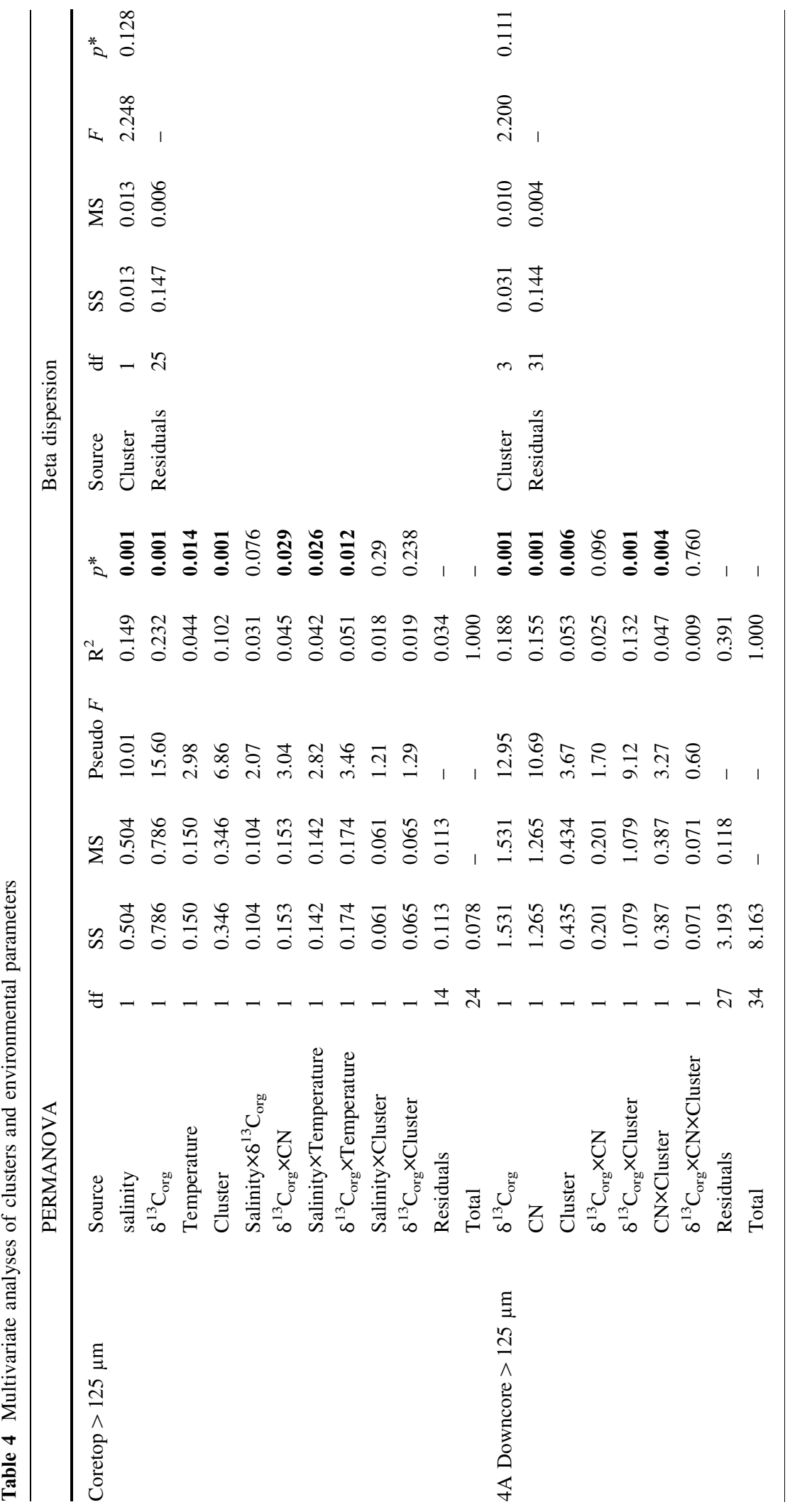




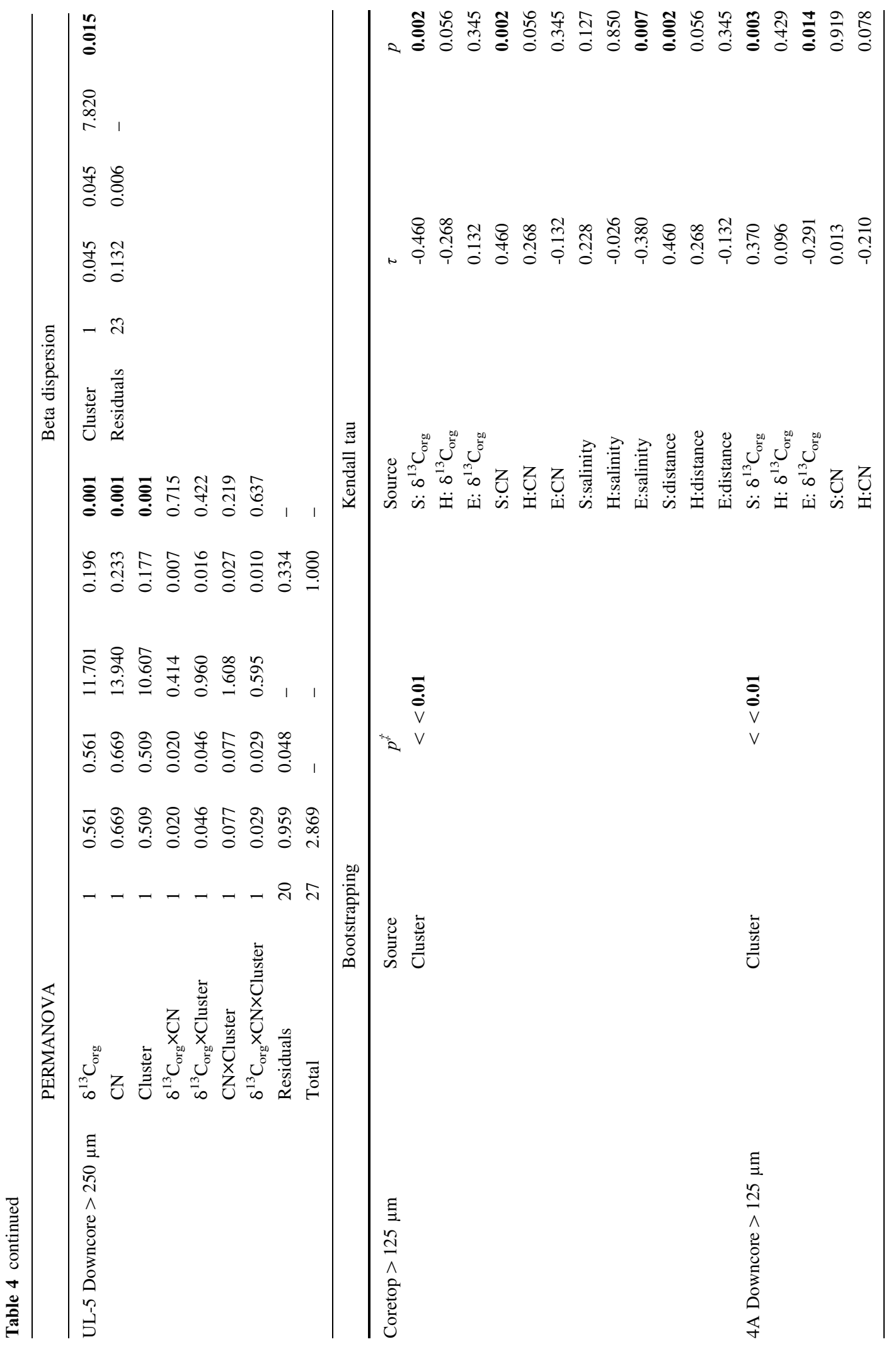




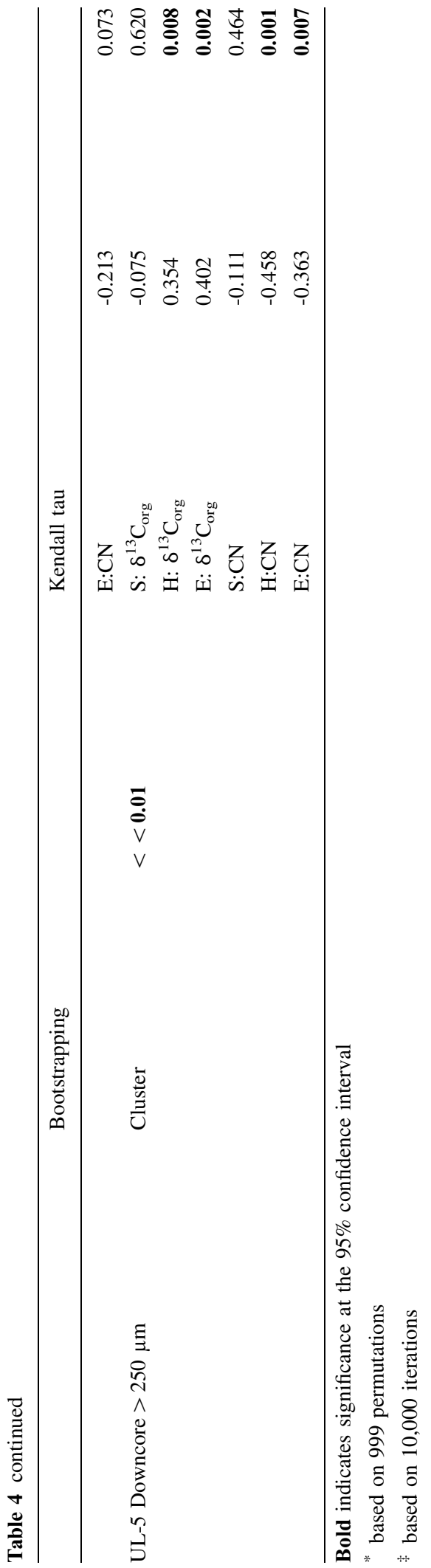

Variable salinity in coastal environments restricts foraminifera occurrence to only those that can withstand a large and fluctuating salinity range (Sen Gupta 1999). Such conditions occur in the northern lagoon and result in low species richness (low $\mathrm{S}$ values, Figs. $4 b, 6 b)$. The pattern of assemblage change along a salinity gradient is found in other Caribbean and Atlantic coastal systems with large salinity ranges. On the mangrove forest coast of French Guiana, Debenay et al. (2002) noted that seasonal salinity oscillations from 20 to 35 psu are accompanied by assemblage compositional changes from Miliammina-dominated (agglutinated) to Ammonia- and Elphidium-dominated. A narrow estuary of Brazil exhibited shallow protected brackish-water assemblages of agglutinated Miliammina and Ammotium taxa and seaward marine-influenced assemblages dominated by A. tepida, E. gunteri, and Bolivina taxa (Debenay et al. 1998), similar to the southern opening of Celestun Lagoon. Collectively, these studies point to salinity as being the most important environmental variable controlling foraminifera distribution in Celestun Lagoon. Based on these associations, we interpret changes in downcore assemblages as representing changes in salinity in the northern lagoon over time.

We acknowledge that analyzing the $>125-\mu \mathrm{m}$ size fraction may exclude some foraminifera species or smaller adult specimens of the species we identified (Table 3, Murray 2006). However, benthic foraminifera at our site and other coastal Yucatan Peninsula sites are characterized by abundant large $(>250 \mu \mathrm{m})$ specimens (Martinez et al. 2018), suggesting we observed most taxa present. Based on the number of taxa identified $(n=26$, Table 3$)$, the number of specimens counted $(n=27,000)$, and the striking differences in assemblage composition observed in the $>125-\mu \mathrm{m}$ fraction (Fig. 4), we consider the statistical relationships noted between environmental parameters and assemblage composition (Table 4) to be real patterns for the modern system, despite exclusion of small foraminifera. Furthermore, $\delta^{13} \mathrm{C}$ and $\mathrm{C}: \mathrm{N}$ of bulk sediment $\mathrm{OM}$ are independent of foraminifera size fractions and are proxies for mangrove and seagrass vegetation that are also distributed along the lagoon salinity gradient (Gonneea et al. 2004; Khan et al. 2017; Carnero-Bravo et al. 2018), supporting interpretation of environments inferred from assemblages. It is possible that 
drying the samples prior to counting may affect preservation of agglutinated taxa (Murray and Alve 1999) and bias assemblage composition. However, the hyaline foraminifera Haynesina germanica observed in the low-energy muddy substrate preferred by agglutinated taxa provides an additional
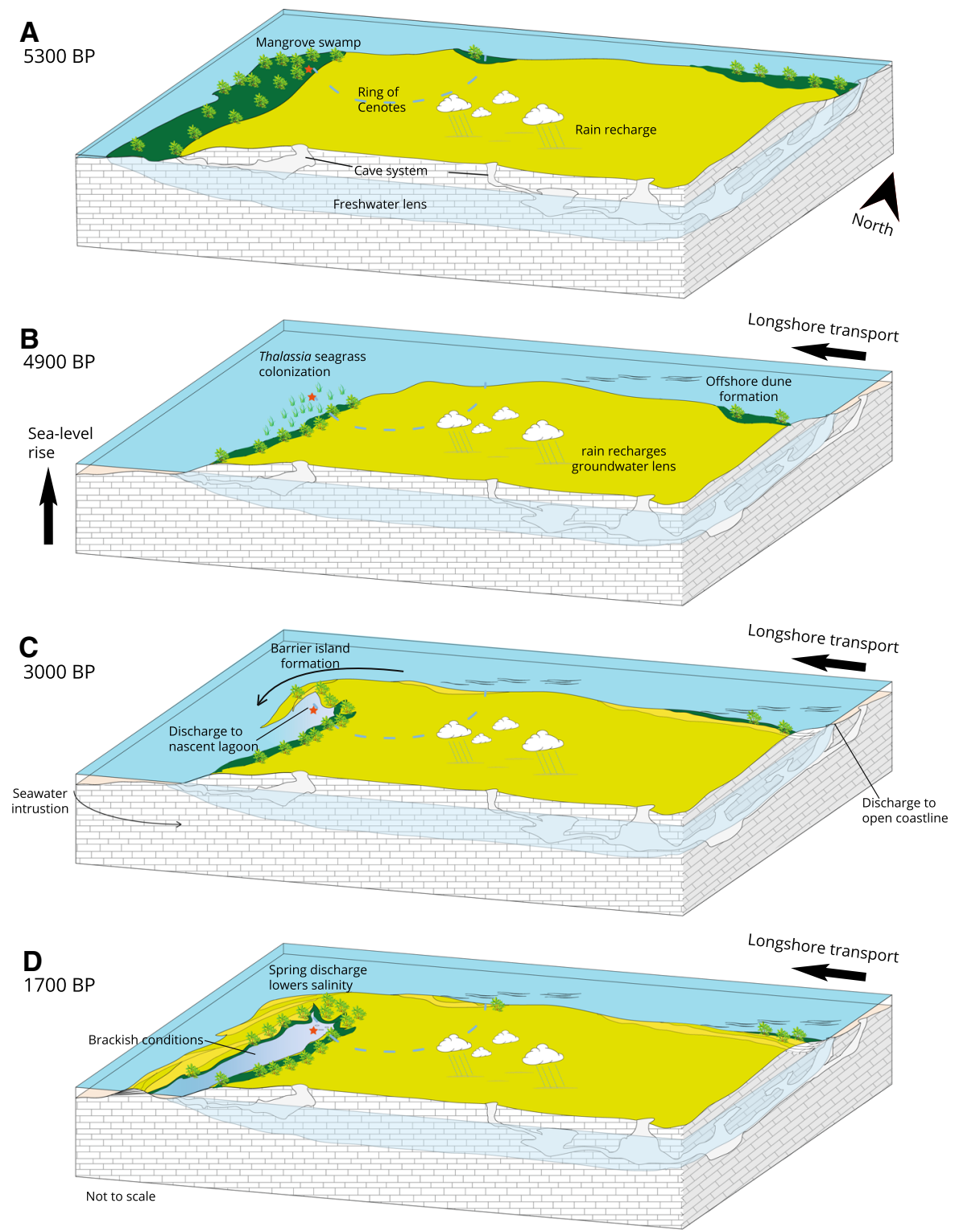

Fig. 7 Conceptual diagram of coastal development around Celestun Lagoon. The star represents site 4A in the present day northern lagoon. A Phase 1, during low sea level the core site is located within a inland low-salinity mangrove pond with Trichohyalus assemblage. B Phase 2, sea level rises beginning $\sim 5100 \mathrm{BP}$, the site is inundated, and coastal marine Thalassia seagrass and Archaias-Laevipeneroplis assemblages colonize by $4900 \mathrm{BP}$. Long-shore drift continues, initiating spits and barrier islands which begin a prolonged period of assemblage change. C Phase 3, decelerating sea-level rise allows for spits and barrier islands to accumulate stably. Bolivina-Hanzawaia-
Rosalina dominates the site but is replaced by AmmoniaElphidium as groundwater lowers salinity the nascent lagoon. D Phase 4, sea level is stable, barrier island coastline expands, and mangroves colonize new shoreline in the lagoon which increases in length. Agglutinated-Haynesina assemblage develops alongside Ammonia-Elphidium. Barrier islands continue to accumulate to present. Precipitation (climate) recharges groundwater throughout all phases, and final assemblage reflects reduction in mixing between the groundwater and seawater as well as absolute decrease in groundwater (and increase in sweater) during droughts 
constraint on the distribution of the AgglutinatedHaynesina assemblage in space and time. We thus are confident in using assemblages defined in the modern environment to infer downcore, paleoenvironmental conditions, specifically changes in salinity.

\section{Lagoon salinity changes-geomorphic processes and climate changes}

The salinity in a restricted lagoon such as Celestun Lagoon can vary as a consequence of two distinct processes that affect the relative contribution of seawater and fresh/brackish groundwater inputs to the lagoon. The first is physical (geomorphic) changes to the coastline (i.e., lagoon restriction or sea level changes) that determine the amount of seawater input to the lagoon, and the second is climate changes that impact regional and local precipitation, which control the amount of groundwater input.

Coastal lagoon morphology in the Yucatan Peninsula was studied by Brady (1972), which remains the most thorough compilation of epikarst sedimentological processes for the peninsula. Brady indicates that modern barrier islands evolved from Pleistocene aeolian dunes on the continental shelf. Once formed, dunes were submerged by rising seas and provide shallow sites to initiate submarine barrier island formation and subaerial aeolian accumulation. Island growth may be episodic, particularly when hurricane overwash adds or removes sediments, but mangrove encroachment rapidly stabilizes island shorelines and facilitates additional shoreline sediment accumulation. Importantly, sediment cores of Nichupte and Holbox Lagoons (Fig. 1c) reflect sharp contacts between basal mangrove peat and overlying carbonate mud, indicating sea level rise and lagoon formation, but are subsequently characterized by faunal shifts from inner-shelf miliolids and clams to restricted lagoon Elphidium and encrusting algae, along with a fining grain size (Brady 1972). Faunal change was attributed to barrier island growth, but constraints on accumulation rate were poor.

More recent work indicates that longshore sediment transport along the Yucatan Peninsula coastline can build barrier island complexes within decades. Based on the observed net $200 \mathrm{~m}$ per 33 years of barrier island progradation offshore near Celestun Lagoon (Fig. 1b, Lowery and Rankey 2017), a 600 m barrier can develop within a century, and around
$30 \mathrm{~km}$ can accumulate in 5000 years. Volumetric rates of sediment transport $\left(35,000 \mathrm{~m}^{3} \mathrm{yr}^{-1}\right)$ along the northwest Yucatan Peninsula coast are sufficient to create the estimated volume of sediment of the Celestun west bank $\left(5.3 \times 10^{7} \mathrm{~m}^{2} \times 3 \mathrm{~m}\right.$ elevation $)$ on this timescale (Appendini et al. 2012). These rates of barrier island development are consistent with gradual accretion of the west Celestun Lagoon bank, resulting in an increase in lagoon length over time and a parallel gradual decrease in the mixing and input of seawater into the northern lagoon. Specifically, sediment deposition at the Celestun coast has resulted from both a Pleistocene dune high point, as indicated by Brady (1972), and a change of shoreline orientation relative to the west-flowing Yucatan Current. Cuevas et al. (2013) noted that offshore dunes tend to accumulate at abrupt changes in shoreline orientation on the north coast of the Yucatan Peninsula, and both the northwest (Celestun) and northeast (Holbox) corners of the Peninsula exhibit extensive barrier-dune complexes.

We note similar barrier-dune complexes from Google Earth ${ }^{\mathrm{TM}}$ near lagoons of Holbox, Ria Lagartos, Dzilam de Bravo, and Progreso, on the north coast of the Yucatan Peninsula, and near Isla Arena and Terminos on the west coast (Fig. 1c). In Terminos Lagoon, the dune-barrier complex called Isla de Carmen consists of $38 \mathrm{~km}$ of shelly coquina (Phleger and Ayala-Castanares 1971). Based on the progradation rate determined by Lowery and Rankey (2017), Isla de Carmen took 6300 years to accumulate, consistent with the island's estimated age of 7000 years based on Holocene sea level terraces (Phleger and Ayala-Castanares 1971). These studies all indicate that the rate and scale of longshore transport and barrier island formation observed today were similar over the Late Holocene.

Although the gradual restriction of seawater into Celestun Lagoon will result in a gradual decrease in salinity, variability superimposed on this trend may be linked to climate-induced changes in groundwater input. Specifically, an increase in the salinity would suggest lower precipitation and possible drought conditions. 


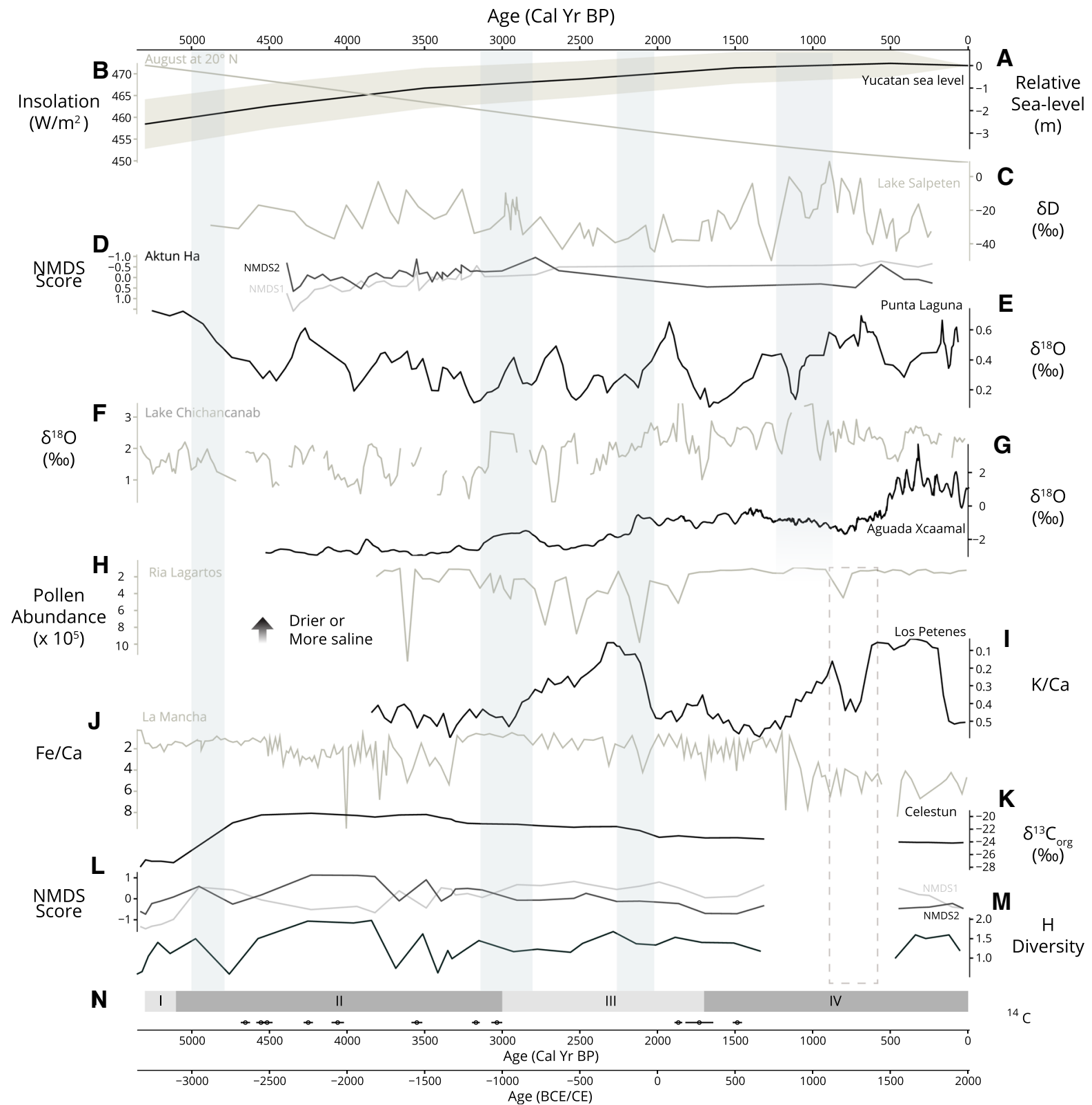

Fig. 8 Summary of oceanographic and paleoclimate records from coasts and lakes around the Yucata Peninsula, Mexico. Climate records have been smoothed using a 4-point rolling average. See Fig. 1 for site locations. A Relative sea-level and 95\% confidence shading (Khan et al. 2017). B Summer (August) insolation at $20^{\circ} \mathrm{N}$ (Laskar et al., 2004). C Hydrogen isotopes of plant wax from Lake Salpeten (Douglas et al. 2015). D NMDS of microfossils and Cenote Aktun Ha (van Hengstrum et al. 2010). E $\delta^{18} \mathrm{O}$ of Pyrgophorus $s p$. in Lake Punta Laguna (Curtis et al. 1998). F $\delta^{18} \mathrm{O}$ of Pyrgophorus coronatus in Lake Chichancanab (Hodell et al. 1995). G $\delta^{18} \mathrm{O}$ of Pyrgophorus coronatus in Aguada X'caamal (closed cenote, Hodell et al. 2005). H Absolute pollen abundance from Ria Lagartos (Aragón-Moreno et al. 2012). I K/Ca of sediment in
Los Petenes (Roy et al. 2017). J Fe/Ca of sediment in La Mancha Lagoon (Arellano-Torres et al. 2019). K $\delta^{13} \mathrm{C}$ of bulk sediment organic matter in Celestun Lagoon (this study). L NMDS scores of foraminiferal assemblages (see Fig. 6a). M H diversity (reflecting total species and absolute abundance) of assemblages. N Phase of lagoon development for Celestun Lagoon (see conceptual diagram, Fig. 7). ${ }^{14} \mathrm{C}$ data points are for this study (Table 2). Shaded columns represent documented dry periods for the north-central Yucatan Peninsula. Dotted box represents possible storm or tsunami deposit in coastal records from the west, south, and east of Celestun Lagoon (Fig. 1). Note that NMDS scores in $\mathbf{D}$ and $\mathbf{I}$ cannot be directly compared and are presented to show relative trends 
Reconstruction of the northern lagoon environmental setting

Based on comparison between observations from core-top sediments along the present-day lagoon transect and downcore data from core $4 \mathrm{~A}$ in the northern lagoon, we suggest that the northern lagoon environment has experienced four phases of development, characterized by distinct environmental settings controlled by climate, sea-level rise, and coastal geomorphic change (Fig. 7). Based on general agreement between cores 4A and UL-5 (ESM), these phases are representative of the entire northern lagoon.

\section{Phase 1 (5300-5100 BP)}

Between 5300 and $5100 \mathrm{BP}$, the northern area of Celestun Lagoon was within a mangrove forest that was isolated from ocean influence. The peat $\delta^{13} \mathrm{C}_{\text {org }}$ value of $-28.26 \%$ indicates mangroves and other terrestrial vegetation (Gonneea et al. 2004; Young et al. 2005; Lamb et al. 2006; Tamalavage et al. 2018) (Fig. 2a), and peat accumulation suggests the absence of oxidants like dissolved oxygen and marine sulfate, consistent with a water-logged freshwater swamp setting. The oligohaline assemblage Trichohyalus observed during this interval is found today in isolated, brackish, groundwater-fed pond environments in Bermuda, supporting interpretation of minimal marine influence (Javaux and Scott 2003). Regional sea level at that time is estimated to have been 2-3 m lower than today (Khan et al. 2017), and a bathymetric slope of $-0.4 \mathrm{~m} \mathrm{~km}^{-1}$ off the northwest Campeche Bank near Celestun (Appendini et al. 2012) would place the coastline $5 \mathrm{~km}$ to the northwest of the current location of Celestun Lagoon, consistent with reduced marine influence. Groundwater was likely provided via springs in the permeable Ring of Cenotes because this Cretaceous-age feature existed prior to Holocene coastal development of the Yucatan Peninsula (Perry et al. 2002). The environment may have resembled the "Petenes" that are present south of Celestun Lagoon today, a periodically flooded black mangrove forest characterized by other marsh and subtropical vegetation, diffuse groundwater inputs, organic-rich sediments, and gastropods (Lowery and Rankey 2017). Based on the low-salinity habitat of
Trichohyalus in Bermuda (Javaux and Scott 2003) and modern groundwater discharge salinity values (Herrera-Silveira 1996), salinity was likely less than $10 \mathrm{psu}$ in these mangrove ponds and probably closer to $3 \mathrm{psu}$, the value of modern groundwater at this site (Young et al. 2008).

We know of no published climate records that span the period between 5300-5100 BP in the northwest Yucatan Peninsula. However, pollen records suggest mesic (semi-moist) tropical forests in the southwest and northeast areas of the Yucatan Peninsula and in Haiti ca. 5200-4800 BP (Hodell et al. 1991; Higuera-Gundy et al. 1999; AragónMoreno et al. 2012; Vela-Pelaez et al. 2018). Regionally wet conditions would provide groundwater to inland mangrove ponds to support Trichohyalus assemblages whose presence in this environment distinguishes this phase from subsequent, more saline conditions in the lagoon.

\section{Phase 2 (5100-3000 BP)}

This phase of over 2000 years is characterized by both changes in foraminifera assemblages and sources of organic matter to the lagoon. Between 5100 and $4900 \mathrm{BP}$, the peat in the core transitions to carbonate mud (Fig. 2a) as $\delta^{13} \mathrm{C}_{\text {org }}$ increases from 28.26 to $-20.21 \%$ and $\mathrm{C}: \mathrm{N}$ decreases from 25 to 11 (Fig. 4a). The Trichohyalus assemblage disappears from Celestun Lagoon, and at 4900 BP the ArchaiasLaevipeneroplis assemblage appears alongside the Ammonia-Elphidium assemblage (Fig. 4a). The $\delta^{13} \mathrm{C}_{\text {org }}$ shift to less negative values indicates an influx of marine particulate matter and seagrass vegetation (Gonneea et al. 2004), corroborated by the Archaias-Laevipeneroplis assemblage which inhabits marine Thalassia seagrass beds (Table 3, Sen Gupta 1999). These data suggest that coastal marine conditions at Celestun Lagoon commenced at this time, probably caused by sea-level rise ca. 5100 BP (Fig. 8). On the Caribbean side of the Yucatan Peninsula, in Puerto Morelos, mangrove peat layers also date to 5000 years ago (Islebe and Sánchez 2002), and coastal caves in Belize and Quintana Roo (Yucatan Peninsula east coast) exhibit basal peats dated to 6000-4000 years ago, with mixed pollen and marine microfossil assemblages suggesting a transition from terrestrial to marine-influenced coastal zones (Brady 1972; Polk et al. 2007; Gabriel et al. 
2009; van Hengstum et al. 2010; Collins et al. 2015). A composite sea-level curve indicates that at 5000 $\mathrm{BP}$, sea level was $2.5 \mathrm{~m}$ lower than today along the north coast of the Yucatan Peninsula (Khan et al. 2017), consistent with the $2.6 \mathrm{~m}$ depth at which peat is found at Celestun (Fig. 2a).

Rising sea level may have been coincident with drought in the northwest Yucatan Peninsula, as seen from records in Lakes Chichancanab and Punta Laguna (Fig. 8; Hodell et al. 1995; Curtis et al. 1998). The Ammonia-Elphidium assemblage at Celestun suggests brackish groundwater discharge was still present, but limited, otherwise the brackish-intolerant Archaias angulatus would not be observed (Hart and Kaesler 1986). This is also consistent with palynological and sedimentary changes of riverine soils in the south Yucatan Peninsula that suggest the onset of droughts ca. $4800 \mathrm{BP}$, which would have impacted the catchment area draining to Celestun Lagoon (Bauer-Gottwein et al. 2011; Aragón-Moreno et al. 2018; Vela-Pelaez et al. 2018). These events occur within chronological uncertainty of the appearance of Archaias-Laevipeneroplis (4900 BP) and may also explain the short duration (century-scale drought event) of this assemblage in the lagoon, which would have disappeared once average precipitation had resumed.

By $4500 \mathrm{BP}$, the Archaias-Laevipeneroplis assemblage was replaced by the Bolivina-HanzawaiaRosalina assemblage with increased abundance of the Ammonia-Elphidium assemblage, while $\delta^{13} \mathrm{C}$ remained between -19 and $-21 \%$ (Fig. 4a), indicating persistent seagrass and marine vegetation from 4500 to $3500 \mathrm{BP}$. The foraminifera community of that time interval greatly resembles the modern assemblage in the southern part of the lagoon (Fig. 4b), suggesting that salinity was likely $<30$ psu, which is inhospitable to Archaias (Hallock and Peebles 1993), but ideal for the other taxa (Table 3). This represents a decrease from a marine salinity supporting Thalassia seagrass and Archaias-Laevipeneroplis at $4800 \mathrm{BP}$, to salinities of $<30 \mathrm{psu}$, likely caused by increased groundwater discharge or reduced contribution of seawater. Dry conditions persisted from 4600 to $4400 \mathrm{BP}$ in Belize (Akers et al. 2016), at 4500 BP in the south-central Yucatan Peninsula (Curtis et al. 1998; Wahl et al. 2014), from 4700 to 3600 BP in the southwest Yucatan Peninsula (Islebe et al. 2019), though conditions in the north- central Yucatan Peninsula at that time are unclear. Hence, precipitation-induced increase in groundwater discharge in Celestun Lagoon at $4500 \mathrm{BP}$ is at odds with available climate data (Fig. 8).

It is likely that formation of barrier islands and spits around the northern lagoon, where springs are located (Fig. 1a, b), reduced mixing between groundwater and seawater, resulting in the observed decrease in salinity (Fig. 7). Highest species richness and diversity occurred between 4500 and $3800 \mathrm{BP}$ (S $=17, \mathrm{H}=1.97$, Fig. $4 \mathrm{a}$ ), similar in magnitude to, and comprised of the same taxa, as the modern central lagoon assemblages (Fig. 4b). Indeed, high diversity is expected of foraminifera that colonize the diverse habitats typical of such an environment (fringing mangrove, brackish-tolerant seagrass, semi-protected lagoon, and unrestricted seawater circulation). West of Celestun Lagoon, across the Gulf of Mexico (Fig. 1c), La Mancha Lagoon in Veracruz, Mexico, also exhibits a rapid change in foraminifera composition between 6500 and $4500 \mathrm{BP}$, attributed to longshore transport and barrier island formation (Arellano-Torres et al. 2019). Initiation of coastal dunes and barrier island formation across the Gulf of Mexico, as sea-level rose, is consistent with apparent freshening and maximum diversity in Celestun Lagoon, despite regionally dry conditions (i.e., the restriction of seawater mixing is more effective in controlling the salinity than the reduction in groundwater input caused by drought). A more recent example (1000 BP) of this process was observed in sediment cores from Nichupte Lagoon on the eastern Yucatan Peninsula (Fig. 1c), where assemblages shifted from an Archaias assemblage to an Ammonia-Elphidium assemblage as barrier islands isolated the lagoon and reduced mixing with seawater (Hart and Kaesler 1986).

From 4500 to $3600 \mathrm{BP}$, diversity decreased as marine taxa progressively disappeared, while mean $\delta^{13} \mathrm{C}(-19.5 \%$ ) and C:N (8.2) changed little (Fig. 4a). the Ammonia-Elphidium assemblage became dominant by $3400 \mathrm{BP}$, while the Bolivina-HanzawaiaRosalina assemblage decreased in abundance, indicating salinity ranged from 20-25 psu based on modern lagoon distributions (Table 3, Fig. 4b). We note, however, that sea level rise during that time (Fig. 8) should have resulted in greater marine influence, not less. Hence, we interpret the shift towards brackish taxa as indicative of greater 
influence of groundwater discharge, which may have been caused by increasingly moist climate between 4500 and $3400 \mathrm{BP}$.

The lower salinity could also be attributed to reduced contribution of seawater related to sand-bar buildup, however rapid fluctuation between dominant assemblages suggests an unstable environment, more likely reflecting climate change rather than more gradual and unidirectional barrier island accumulation. Between 3600 and 3400 BP (Fig. 4a), assemblages oscillated between Bolivina-Hanzawaia-Rosalina and Ammonia-Elphidium, accompanied by large changes in $\mathrm{S}$ and $\mathrm{H}$. Specifically, because salinity correlates best with assemblage distribution (Table 4), shifting relative abundances between these two assemblages suggest fluctuating lagoon salinity, and is not consistent with the generally unidirectional formation of barrier islands. Instead, the lagoon geometry at that time was such that relatively small changes in absolute groundwater discharge greatly affected the salinity in the lagoon, thereby impacting foraminifera assemblages (Fig. 7). These relatively short-term salinity fluctuations were likely related to climate changes, such as variability in the ITCZ position and regional precipitation, as manifested by high variability in other climate records during this period (Fig. 8; Hughen et al. 1996; Douglas et al. 2016b; AragónMoreno et al. 2018). A wet period ca. $3500 \mathrm{BP}$ is supported by negative oxygen isotope excursions in lake records from Lake Salpeten and mesic forest pollen from Lake Silvituc in the southwest peninsula (Wahl et al. 2006; Douglas et al. 2015; Vela-Pelaez et al. 2018). However, dry conditions are indicated at the same time by the oxygen records from Lakes Chichancanab and Puerto Arturo in the central peninsula (Hodell et al. 1991; Wahl et al. 2014). Indeed, at $3500 \mathrm{BP}$ our data best match the $\mathrm{Fe} / \mathrm{Ca}$ data (a runoff proxy) of La Mancha Lagoon, west of Celestun Lagoon (Figs. 1c, 8), across the Gulf of Mexico, demonstrating the regional link between climate and assemblage variability in the Gulf of Mexico southern coasts.

In Celestun Lagoon, from 3400 to $3000 \mathrm{BP}$, the Ammonia-Elphidium assemblage became dominant and Bolivina-Hanzawaia-Rosalina decreased in prevalence, indicating a reduction in salinity, while a decrease in $\delta^{13} \mathrm{C}$ suggests more mangrove-derived carbon in sediments (Fig. 4a). It is difficult to say whether these salinity and carbon trends are the result of barrier island growth or climate. Mangrove forest cover in particular may respond to both wetter climate and/or to additional shoreline to colonize. $\mathrm{K} / \mathrm{Ca}$ ratios in nearby Los Petenes and $\mathrm{Fe} / \mathrm{Ca}$ ratios in La Mancha Lagoon suggest reduced erosion and hence dry conditions across the southern Gulf of Mexico (Roy et al. 2017; Arellano-Torres et al. 2019), whereas $\delta^{18} \mathrm{O}$ records from Punta Laguna and $\delta \mathrm{D}$ records from Lake Salpeten imply wet conditions over the east and south Yucatan Peninsula around 3000 BP (Fig. 8; Curtis et al. 1998; Douglas et al. 2015). The general divide between dry northwest and wet southeast among records in the region may suggest that a specific atmospheric circulation pattern drove precipitation at that time. Indeed, previous studies indicate changes in the positions of the ITCZ, North Atlantic Subtropical High, and descending limb of Walker circulation (Metcalfe et al. 2015; Bhattacharya et al. 2017).

Overall, Phase 2 is distinguished by the apparent faunal succession from coastal marine taxa to brackish lagoon taxa (Fig. 4a), despite a sea-level rise of $1 \mathrm{~m}$ (Khan et al. 2017), with occasional oscillations between dominant assemblages during periods of climate variability (Fig. 8). Close agreement among observed sediment transport rates (Appendini et al. 2012), calculated barrier island aggradation time (Lowery and Rankey 2017), and transition between dominant foraminifera assemblages (Fig. 4a), suggests coastal geomorphology continued to influence the hydrogeology and salinity of Celestun Lagoon during Phase 2, with assemblages exhibiting variable sensitivity to changes in groundwater discharge induced by climate at that time (Fig. 7).

\section{Phase 3 (3000-1700 BP)}

Between 3000 and $1700 \mathrm{BP}$, species richness decreased and assemblages were dominated by the near-exclusive presence of Ammonia-Elphidium (Fig. 4a). Bulk sediment $\delta^{13} \mathrm{C}_{\text {org }}$ decreased from 19.51 to $-23.27 \%$ o by $1700 \mathrm{BP}$, indicating vegetation shifted from seagrass/phytoplankton to a greater proportion of mangroves. The decrease in species richness indicates a more homogenous setting (fewer habitats) compared to Phase 2 and was probably similar to the modern northern lagoon (Fig. 4b). Celestun Lagoon salinity during this phase was 
likely15-25 psu, indicated by the Ammonia-Elphidium assemblage and decrease in species richness (Fig. 4b). This trend is consistent with the ongoing barrier island buildup that reduced seawater input. However, at 2500 BP (105-106 cm), Quinqueloculina bicarinata and Hanzawaia concentrica appear briefly and Ammonia-Elphidium abundance decrease, suggesting a reduction in groundwater and more marine influence in the lagoon (Fig. 4a). This change corresponds to drought conditions noted in Lake Chichancanab (Central Yucatan Peninsula), and Macal Chasm (Belize) speleothem records ca. 2600 BP (Hodell et al. 1991; Akers et al. 2016). The generally drier conditions on the Yucatan Peninsula from 3000 to $2000 \mathrm{BP}$ (Douglas et al. 2015) also match the timing of increased marine influence in Celestun Lagoon, as suggested by slight carbon isotope changes from -21.7 to $-21.5 \%$ o (indicating greater input of marine particulate matter). After 2000 BP, Ammonia-Elphidium returned, and the conclusion of this phase is the onset of the brackish, semi-protected lagoon environmental conditions that characterize the present-day northern lagoon.

\section{Phase 4 (1700 BP-present)}

The last 1700 years of northern Celestun Lagoon history are characterized by the appearance of the Agglutinated-Haynesina assemblage, low species richness $(\mathrm{S}=7), \delta^{13} \mathrm{C}_{\mathrm{org}}$ decrease from -22.97 to $24.22 \%$, and variable $\mathrm{C}: \mathrm{N}($ mean=7.5). Elphidium galvestonense disappeared, but other taxa of the Ammonia-Elphidium assemblage (Fig. 5c) remained, alongside increased abundance of $Q$. laevigata. These conditions persist to the present, thus representing the onset of modern conditions in the northern lagoon beginning at $1700 \mathrm{BP}$. The Agglutinated-Haynesina assemblage indicates increased muddy substrate, which is observed in the protected mangrove lagoon today and is consistent with mangrove forest expansion, indicated by decreasing carbon isotope values (Fig. 4a). Mangrove expansion around Celestun Lagoon is consistent with expansion of mangrove forest documented elsewhere in the Caribbean (Peros et al. 2007). Though barrier islands provide more land for mangrove colonization, the effect is local, so a regional expansion of mangroves suggests regional climate influence. Onset of moister climate ca. 1700 $\mathrm{BP}$ is consistent with observation in the
Chichancanab and Salpeten lake records (Fig. 8; Hodell et al. 1995; Douglas et al. 2015).

The age-depth model indicates that the coarse bioclastic layer at $35 \mathrm{~cm}$ depth (Fig. 2b) begins at $1300 \mathrm{BP}$, or about 700 Common Era (CE). In core 4A this layer consists of an increase in absolute abundance of foraminifera in the Ammonia-Elphidium assemblage and a pronounced decrease in agglutinated taxa and $\mathrm{H}$ and $\mathrm{E}$ indices (Fig. 4b). In the southern lagoon, abundant bivalves and fragments are noted. This interval coincides with the well-documented Maya droughts (Douglas et al. 2016b), which implies decreased groundwater discharge in Celestun Lagoon. Although an increase in the polyhaline assemblage Ammonia-Elphidium could be a response to increased salinity, the lack of fine mud across the cores would imply that authigenic carbonate precipitation was reduced in the lagoon at the same time. If included in the age-depth model, radiocarbon sampled at $31 \mathrm{~cm}$ (Table $2,1485{ }^{14} \mathrm{C}$ yr) causes a rapid change in slope in the age-depth regression line that results in abrupt decrease in sedimentation to $0.2 \mathrm{~mm} \mathrm{y}^{-1}$. This slowed sedimentation rate is not consistent with the $1.5 \mathrm{~mm} \mathrm{y}^{-1}$ rate determined by ${ }^{210} \mathrm{~Pb}_{\text {excess }}$ (Fig. 3) or rising sea level at this coastal setting (Fig. 8, Khan et al. 2017). We thus interpret this lagoon-wide layer to be caused by storm erosion or a tsunami. Hurricanes are known to sort and transport shelf foraminifera into coastal systems (Murray 2006), and identified features of this coarse layer, including the lack of fine sediments or agglutinated taxa, are consistent with such an event. The rapid increase in absolute abundance of Ammonia and Elphidium, which occurs in hurricane overwash deposits on the Atlantic coast of the United States (Collins et al. 1999), also supports this interpretation. The presence of an erosive shell layer representing the missing interval, 1300 to $500 \mathrm{BP}$, provides some paleoclimate information, as other studies suggest increased hurricane activity from 800 to $1350 \mathrm{AD}$ (1150-600 BP) in the Caribbean (Peros 2015), although our age model uncertainty is high near the shell layer at $35 \mathrm{~cm}$ (Fig. 3).

Alternatively, the bioclastic layer could represent a tsunami deposit, likely from submarine continental slope failure (Horrillo et al. 2013). Holocene sealevel rise has been suggested as a cause of slope failure from water overburden pressure (Smith et al. 2013), and in the Gulf of Mexico, sea level has risen 
$9 \mathrm{~m}$ during the last $7.8 \mathrm{ka}$ (Blum et al. 2002). Continental slopes may also fail because of additional sediment load, which would be expected from increased continental weathering and riverine transport to coasts. $\mathrm{Fe} / \mathrm{Ca}$ and $\mathrm{K} / \mathrm{Rb}$ ratios in sediments of La Mancha Lagoon (Fig. 1c), indicate increased detrital input and coastal weathering at $1000 \mathrm{BP}$ (Arellano-Torres et al. 2019). The timing is coincident with the high-energy shell deposit in Celestun Lagoon (Figs. 2, 3), and evidence of a tsunami deposit might be recognized in sediment cores from other lagoons around the southern Gulf of Mexico. Brady (1972) noted an erosional contact with increased grain size at $20 \mathrm{~cm}$ depth in Holbox Lagoon (Fig. 1c). South of Celestun in Los Petenes (Fig. 1c), sediments transition from peat at $38 \mathrm{~cm}$ to silt between 35 and $15 \mathrm{~cm}$ and are dated around 700 BP (1300 CE) with a spike in $\mathrm{K} / \mathrm{Ca}$ that indicates rapid erosion inland (Roy et al. 2017; Fig. 8). Rapid erosion from rainfall is unlikely during the Terminal Classic Maya mega-droughts of this time (Hodell et al. 1995; Douglas et al. 2016b), further implying a catastrophic depositional event such as a tsunami inundation and subsequent outwash. Lastly, an anomalous berm of unsorted boulders and sand on the Caribbean coast of the Yucatan Peninsula has been interpreted as a potential tsunami deposit with a radiocarbon age of $1500 \mathrm{BP}$ (Shaw and Benson 2015). At our site, the occurrence of a single (anomalous) shell layer with an upper age limit of $1300 \mathrm{BP}$ suggests that the causal event was relatively uncommon, further supporting a tsunami as opposed to hurricanes, which are common in the region. Additional research is required to better characterize the tsunami history of the Gulf of Mexico, but a tsunami remains a plausible cause of the shell layer at $35 \mathrm{~cm}$.

From 500 BP to present, the Ammonia-Elphidium and Agglutinated-Haynesina assemblages dominate, with a notable increase in $A$. tepida at $150 \mathrm{BP}$, or about $1800 \mathrm{CE}$ (Fig. 4a). The only other occurrence of abundant $A$. tepida was during Phase 1, at 5200 BP. Thin-walled $A$. tepida thrive in low-salinity, protected conditions (Table 3, Murray 2006). Barrier island aggradation is unlikely to have altered the entire lagoon geometry substantially over just the last few hundred years, so the increase in $A$. tepida may be a response to low-salinity conditions, induced by wet climate. The nearest speleothem-derived oxygen isotope record, from Tecoh Cave $(100 \mathrm{~km}$ west of Celestun Lagoon), shows three century-scale pulses of relatively wet conditions occurred during the Medieval Warm Period and Little Ice Age (MedinaElizalde et al. 2010), and a wet interval is also noted in Belize speleothems (Kennett et al. 2012). A diatom record from Cenote San Jose Chulchaca, $22 \mathrm{~km}$ east of Celestun Lagoon indicates a decrease in salinity over the last 800 years (Whitmore et al. 1996; Hodell et al. 2005). However, Whitmore et al. (1996) did not note the same trend in Cenote Sayaucil (north-central Yucatan lowlands). Furthermore, the pollen record from Lake San Jose suggests a decline of forest taxa that depend on high rainfall at the same time the cenote was freshening (Hodell et al. 2005), a trend corroborated by pollen and microfossil observations from Aguada X'caamal (75 km southeast of Celestun Lagoon) that imply drying in the northwest region during the Little Ice Age (600 to $100 \mathrm{BP}$ ) (Hodell et al. 2005). Together these records suggest both increased precipitation and increased evaporation for the northwest Yucatan Peninsula, which today has the highest evapotranspiration potential of the entire region (Bauer-Gottwein et al. 2011). Phase 4 of Celestun Lagoon development is thus characterized by expanding mangrove forests during a period of variable precipitation. Ammonia-Elphidium and $\mathrm{Ag}$ glutinated-Haynesina assemblages dominate foraminifera composition of the northern semi-protected habitat with a wide range of salinity, features observed in the modern northern lagoon today.

\section{Conclusions}

This study presents the oldest paleoenvironmental record currently available for the northwest corner of the Yucatan Peninsula. Over the past 5300 years, Celestun Lagoon, on the northwest coast of the Yucatan Peninsula, has evolved from an inland mixed mangrove marsh saturated by groundwater, to a protected brackish lagoon surrounded by mangrove forest. We identified three primary controls for this change: sea level rise, coastal barrier island buildup and climate change. Geomorphic control of lagoon salinity, via reduced contribution of seawater, is a first-order control on the composition of benthic foraminifera assemblages that trend from marine to brackish taxa over time. Importantly, the 5000-year 
age of our record suggests barrier island aggradation, and thus lagoon formation, occurred on Holocene timescales, and led to development of these important features on the modern coastline of the Yucatan Peninsula. Thus, studies seeking to interpret causes of paleoenvironmental change on the coastal Yucatan Peninsula will need to account for changes in lagoon basin size and shape, which impact the proxy environmental records. When geomorphologic change is considered, excursions from brackish to marine taxa during lagoon development signify decreases in groundwater discharge and hence reduced precipitation over the catchment area, which is responsible for recharging the groundwater. Agreement between the Celestun sediment record and paleoclimate records from the far western and southern regions of the Gulf of Mexico suggest that Celestun Lagoon sediments reflect regional climatic events and thus regionally integrated precipitation. The inferred paleoecologic variability presented in this study, derived from processes of barrier island aggradation, sea-level rise, and climate-induced change in groundwater discharge, will contribute to future interpretations of paleoenvironmental and paleoclimate archives found along the coast of the Yucatan Peninsula.

\section{Data Repository}

All data presented in this study are available in the National Oceanic and Atmospheric Administration (NOAA) Paleoclimatology Database at the URL ncdc.noaa.gov/paleo-search/study/29171. Sediment cores are stored at the National Lacustrine Core Facility (LacCore), University of Minnesota, Minneapolis, MN, USA), and cores, core images, metadata, and bulk physical properties can be retrieved using the project code FLAM-CEL09.

Acknowledgements We thank UC MEXUS for funding this project and are grateful for the logistical work and technical assistance with sediment metadata provided by LacCore. Kyle Hardage was supported by the NSF Graduate Research Fellowship Program. Thank you to the Geological Society of America for providing graduate funding for radiocarbon dating at Lawrence Livermore National Lab. We give thanks for the generous instrument use provided by the US Geological Survey for lead-210 dating and UL-5 core imaging, particularly for the assistance provided by Tom Lorenson and Mike Torreson. We thank Dave Wahl for help with data resources. Thanks are due to Jenna Hill and two anonymous reviewers for very helpful comments, Scott Hardage for GIS mapping assistance, Chelsey Lindo and Frankie Lon for lab assistance, and CJ Vigil and Colin Carney for stable carbon analytical expertise.

Funding University of California Institute for Mexico and the United States, 07/2008-2009,Adina Paytan, 12/2016, Kyle Hardage, National Science Foundation, Graduate Research Fellowsihp Program, Kyle Hardage, Geological Society of America, 2017, Kyle Hardage, Dr. Earl H. Myers \&amp; Ethel M. Myers Oceanographic \&amp; Marine Biology Trust, 2018, Kyle Hardage

Open Access This article is licensed under a Creative Commons Attribution 4.0 International License, which permits use, sharing, adaptation, distribution and reproduction in any medium or format, as long as you give appropriate credit to the original author(s) and the source, provide a link to the Creative Commons licence, and indicate if changes were made. The images or other third party material in this article are included in the article's Creative Commons licence, unless indicated otherwise in a credit line to the material. If material is not included in the article's Creative Commons licence and your intended use is not permitted by statutory regulation or exceeds the permitted use, you will need to obtain permission directly from the copyright holder. To view a copy of this licence, visit http://creativecommons.org/licenses/by/4.0/.

\section{References}

Akers PD, Brook GA, Railsback LB, Liang F, Iannone G, Webster JW, Reeder PP, Cheng H, Edwards RL (2016) An extended and higher-resolution record of climate and land use from stalagmite MC01 from Macal Chasm, Belize, revealing connections between major dry events, overall climate variability, and Maya sociopolitical changes. Palaeogeogr Palaeoclimatol Palaeoecol 459:268-288. https://doi.org/10.1016/j.palaeo.2016.07. 007

Anderson MJ (2001) A new method for non-parametric multivariate analysis of variance: NON-PARAMETRIC MANOVA FOR ECOLOGY. Austral Ecol 26:32-46. https://doi.org/10.1111/j.1442-9993.2001.01070.pp.x

Anderson MJ, Ellingsen KE, McArdle BH (2006) Multivariate dispersion as a measure of beta diversity. Ecol Lett 9:683693. https://doi.org/10.1111/j.1461-0248.2006.00926.x

Appendini CM, Salles P, Mendoza ET, Lopez J, Torres-Freyermuth A (2012) Longshore Sediment Transport on the Northern Coast of the Yucatan Peninsula. J Coast Res 285:1404-1417. https://doi.org/10.2112/JCOASTRES-D11-00162.1

Aragón-Moreno AA, Islebe GA, Roy PD, Roy PD, TorrescanoValle N, Mueller AD (2018) Climate forcings on vegetation of the southeastern Yucatán Peninsula (Mexico) during the middle to late Holocene. Palaeogeogr 
Palaeoclimatol Palaeoecol 495:214-226. https://doi.org/ 10.1016/j.palaeo.2018.01.014

Aragón-Moreno AA, Islebe GA, Torrescano-Valle N (2012) A $\sim 3800$-yr, high-resolution record of vegetation and climate change on the north coast of the Yucatan Peninsula. Rev Palaeobot Palynol 178:35-42. https://doi.org/10. 1016/j.revpalbo.2012.04.002

Arellano-Torres E, Correa-Metrio A, López-Dávila D, Escobar J, Curtis JH, Cordero-Oviedo MC (2019) Mid to late Holocene hydrological and sea-level change reconstructions from La Mancha coastal lagoon, Veracruz, Mexico. Palaeogeogr Palaeoclimatol Palaeoecol 520:150-162. https://doi.org/10.1016/j.palaeo.2019.01.033

Bauer-Gottwein P, Gondwe BRN, Charvet G, Marín LE, Rebolledo-Vieyra M, Merediz-Alonso G (2011) Review: The Yucatán Peninsula karst aquifer, Mexico. Hydrogeol J 19:507-524. https://doi.org/10.1007/s10040-010-0699-5

Bhattacharya T, Chiang JCH, Cheng W (2017) Ocean-atmosphere dynamics linked to 800-1050 CE drying in mesoamerica. Quat Sci Rev 169:263-277. https://doi.org/ 10.1016/j.quascirev.2017.06.005

Blaauw M, Christen JA (2011) Flexible paleoclimate age-depth models using an autoregressive gamma process. Bayesian Anal 6:457-474. https://doi.org/10.1214/11-BA618

Blum MD, Carter AE, Zayac T, Goble R (2002) Middle Holocene sea-level and evolution of the gulf of Mexico coast (USA). J Coast Res 36:65-80. https://doi.org/10. 2112/1551-5036-36.sp1.65

Bond G, Kromer B, Beer J, Muscheler R, Evans MN, Showers W, Hoffmann S, Lotti-Bond R, Hajdas I, Bonani G (2001) Persistent solar influence on north Atlantic climate during the Holocene. Science 294:2130-2136. https://doi.org/10. $1126 /$ science. 1065680

Brady MJ (1972) Sedimentology and diagenesis of carbonate muds in coastal lagoons of northeast Yucatan. Unpublisehd Thesis, Rice University

Buzas MA, Hayek L-AC (1998) SHE analysis for biofacies identification. J Foraminifer Res 28:233-239

Carnero-Bravo V, Sanchez-Cabeza J-A, Ruiz-Fernández AC, Merino-Ibarra M, Corcho-Alvarado JA, Sahli H, Hélie JF, Preda M, Zavala-Hidalgo J, Díaz-Asencio M, HillaireMarcel C (2018) Sea level rise sedimentary record and organic carbon fluxes in a low-lying tropical coastal ecosystem. CATENA 162:421-430. https://doi.org/10. 1016/j.catena.2017.09.016

Collins SV, Reinhardt EG, Werner CL, Le Maillot C, Devos F, Rissolo D (2015) Late Holocene mangrove development and onset of sedimentation in the Yax Chen cave system (Ox Bel Ha) Yucatan, Mexico: Implications for using cave sediments as a sea-level indicator. Palaeogeogr Palaeoclimatol Palaeoecol 438:124-134. https://doi.org/ 10.1016/j.palaeo.2015.07.042

Collins ES, Scott DB, Gayes PT (1999) Hurricane records on the South Carolina coast: Can they be detected in the sediment record? Quat Int 56:15-26. https://doi.org/10. 1016/S1040-6182(98)00013-5

Cuevas E, Liceaga-Correa M, Rincón-Sandoval LA, Mexicano-Cíntora G, Arellano-Méndez L, Euán-Ávila J, Hernández-Núñez H, Mulsow S (2013) Morphological and sedimentological assessment of submarine dune fields on the coast of Yucatan, Mexico. Cienc Mar 39:83-99. https://doi.org/10.7773/cm.v39i1.2152

Culver SJ (1990) Benthic foraminifera of Puerto Rican Mangrove-Lagoon systems: potential for paleoenvironmental interpretations. Palaios 5:34-51. https://doi.org/10.2307/ 3514995

Curtis JH, Brenner M, Hodell DA, Balser RA, Islebe GA, Hooghiemstra H (1998) A multi-proxy study of Holocene environmental change in the Maya Lowlands of Peten, Guatemala. J Paleolimnol 19:139-159. https://doi.org/10. 1023/A:1007968508262

Davis JC (2002) Statistics and data analysis in geology. John Wiley \& Sons, New York

Debenay J-P, Beck Eichler B, Duleba W, Bonetti C, EichlerCoelho P (1998) Water stratification in coastal lagoons: its influence on foraminiferal assemblages in two Brazilian lagoons. Mar Micropaleontol 35:67-89. https://doi.org/10. 1016/S0377-8398(98)00011-5

Debenay J-P, Guillou J-J (2002) Ecological transitions indicated by foraminiferal assemblages in paralic environments. Estuaries 25:1107-1120. https://doi.org/10. 1007/BF02692208

Debenay J-P, Guiral D, Parra M (2002) Ecological Factors Acting on the Microfauna in Mangrove Swamps. The Case of Foraminiferal Assemblages in French Guiana. Estuar Coast Shelf Sci 55:509-533. https://doi.org/10. 1006/ecss.2001.0906

Douglas PMJ, Brenner M, Curtis JH (2016a) Methods and future directions for paleoclimatology in the Maya Lowlands. Glob Planet Change 138:3-24. https://doi.org/10. 1016/j.gloplacha.2015.07.008

Douglas PMJ, Demarest AA, Brenner M, Canuto MA (2016b) Impacts of climate change on the collapse of lowland Maya Civilization. Annu Rev Earth Planet Sci 44:613645. https://doi.org/10.1146/annurev-earth-060115012512

Douglas PMJ, Pagani M, Canuto MA, Brenner M, Hodell DA, Eglinton TI, Curtis JH (2015) Drought, agricultural adaptation, and sociopolitical collapse in the Maya Lowlands. Proc Natl Acad Sci 112:5607-5612. https://doi.org/ 10.1073/pnas.1419133112

Fletcher WJ, Zielhofer C, Mischke S, Bryant C, Xu X, Fink D (2017) AMS radiocarbon dating of pollen concentrates in a karstic lake system. Quat Geochronol 39:112-123. https://doi.org/10.1016/j.quageo.2017.02.006

Gabriel JJ, Reinhardt EG, Peros MC, Davidson DE, van Hengstum PJ, Beddows PA (2009) Palaeoenvironmental evolution of Cenote Aktun Ha (Carwash) on the Yucatan Peninsula, Mexico and its response to Holocene sea-level rise. J Paleolimnol 42:199-213. https://doi.org/10.1007/ s10933-008-9271-x

Gischler E, Hudson JH (2004) Holocene development of the Belize Barrier Reef. Sediment Geol 164:223-236. https://doi.org/10.1016/j.sedgeo.2003.10.006

Gonneea ME, Paytan A, Herrera-Silveira JA (2004) Tracing organic matter sources and carbon burial in mangrove sediments over the past 160 years

Hallock P, Peebles MW (1993) Foraminifera with chlorophyte endosymbionts: Habitats of six species in the Florida Keys. Mar Micropaleontol 20:277-292. https://doi.org/10. 1016/0377-8398(93)90037-X 
Hart AM, Kaesler RL (1986) Temporal changes in Holocene lagoonal assemblages of foraminifera from northeastern Yucatan Peninsula, Mexico. J Foraminifer Res 16:98-109. https://doi.org/10.2113/gsjfr.16.2.98

Haug GH, Hughen KA, Sigman DM, Peterson LC, Röhl U (2001) Southward Migration of the Intertropical Convergence Zone Through the Holocene. Science 293:13041308. https://doi.org/10.1126/science. 1059725

van Hengstum PJ, Maale G, Donnelly JP, Albury NA, Onac $\mathrm{BP}$, Sullivan RM, Winkler TS, Tamalavage AE, MacDonald D (2018) Drought in the northern Bahamas from 3300 to 2500 years ago. Quat Sci Rev 186:169-185. https://doi.org/10.1016/j.quascirev.2018.02.014

van Hengstum PJ, Reinhardt EG, Beddows PA, Gabriel JJ (2010) Linkages between Holocene paleoclimate and paleohydrogeology preserved in a Yucatan underwater cave. Quat Sci Rev 29:2788-2798. https://doi.org/10. 1016/j.quascirev.2010.06.034

van Hengstum PJ, Scott DB, Gröcke DR, Charette MA (2011) Sea level controls sedimentation and environments in coastal caves and sinkholes. Mar Geol 286:35-50. https://doi.org/10.1016/j.margeo.2011.05.004

van Hengstum PJ, Winkler TS, Tamalavage AE, Sullivan RM, Little SN, MacDonald D, Donnelly JP, Albury NA (2020) Holocene sedimentation in a blue hole surrounded by carbonate tidal flats in The Bahamas: Autogenic versus allogenic processes. Mar Geol 419:106051. https://doi. org/10.1016/j.margeo.2019.106051

Herrera-Silveira JA (1996) Salinity and nutrients in a tropical coastal lagoon with groundwater discharges to the Gulf of Mexico. Hydrobiologia 321:165-176. https://doi.org/10. 1007/BF00023172

Herrera-Silveira JA, R. JR, J. AZ, (1998) Overview and characterization of the hydrology and primary producer communities of selected coastal lagoons of Yucatán, México. Aquat Ecosyst Health Manag 1:353-372. https://doi.org/10.1080/14634989808656930

Herrera-Silveira JA (1994) Spatial heterogeneity and seasonal patterns in a tropical coastal lagoon. J Coast Res 738-746

Higuera-Gundy A, Brenner M, Hodell DA, Curtis JH, Leyden BW, Binford MW (1999) A 10,300 14C y Record of Climate and Vegetation Change from Haiti. Quat Res 52:159-170. https://doi.org/10.1006/qres.1999.2062

Hodell DA, Brenner M, Curtis JH, Medina-González R, Ildefonso-Chan CE, Albornaz-Pat A, Guilderson TP (2005) Climate change on the Yucatan Peninsula during the Little Ice Age. Quat Res 63:109-121. https://doi.org/10.1016/j. yqres.2004.11.004

Hodell DA, Curtis JH, Brenner M (1995) Possible role of climate in the collapse of Classic Maya civilization. Nature 375:391-394. https://doi.org/10.1038/375391a0

Hodell DA, Curtis JH, Jones GA, Higuera-Gundy A, Brenner M, Binford MW, Dorsey KT (1991) Reconstruction of Caribbean climate change over the past 10,500 years. Nature 352:790-793. https://doi.org/10.1038/352790a0

Horrillo J, Wood A, Kim G-B, Parambath A (2013) A simplified 3-D Navier-Stokes numerical model for landslidetsunami: Application to the Gulf of Mexico. J Geophys Res Oceans 118:6934-6950. https://doi.org/10.1002/ 2012JC008689
Hughen KA, Overpeck JT, Peterson LC, Anderson RF (1996) The nature of varved sedimentation in the Cariaco Basin, Venezuela, and its palaeoclimatic significance. Geol Soc Lond Spec Publ 116:171-183. https://doi.org/10.1144/ GSL.SP.1996.116.01.15

Islebe GA, Carrillo-Bastos A, Aragón-Moreno AA, ValdezHernández M, Torrescano-Valle N, Cabanillas-Terán N (2019) Holocene paleoecology and paleoclimatology of South and Southeastern Mexico: a palynological and geospatial approach. In: Torrescano- Valle N, Islebe GA, Roy PD (eds) The Holocene and Anthropocene environmental history of Mexico: a paleoecological approach on Mesoamerica. Springer, Cham, pp 195-207

Islebe G, Sánchez O (2002) History of late Holocene vegetation at Quintana Roo, Caribbean coast of Mexico. Plant Ecol 160:187-192

Jaijel R, Glover JB, Rissolo D, Beddows PA, Smith D, BenAvraham Z, Goodman-Tchernov B (2018) Coastal reconstruction of Vista Alegre, an ancient maritime Maya settlement. Palaeogeogr Palaeoclimatol Palaeoecol 497:25-36. https://doi.org/10.1016/j.palaeo.2018.02.003

Javaux EJ, Scott DB (2003) Illustration of modern benthic foraminifera from Bermuda and remarks on distribution in other subtropical/tropical areas. Palaeontol Electron 6:29

Juggins S (2017) rioja: Analysis of Quaternary Science Data. R package version $0.9-21$. https://cran.r-project.org/pack age $=$ rioja

Kennett DJ, Breitenbach SFM, Aquino VV, Asmerom Y, Awe J, Baldini JUL, Bartlein P, Culleton BJ, Ebert C, Jazwa C, Macri MJ, Marwan N, Polyak V, Prufer KM, Ridley HE, Sodemann H, Winterhalder B, Haug GH (2012) Development and disintegration of Maya political systems in response to climate change. Science 338:788-791. https://doi.org/10.1126/science.1226299

Khan NS, Ashe E, Horton BP, Dutton A, Kopp RE, Brocard G, Engelhart SE, Hill DF, Peltier WR, Vane CH, Scatena FN (2017) Drivers of Holocene sea-level change in the Caribbean. Quat Sci Rev 155:13-36. https://doi.org/10.1016/ j.quascirev.2016.08.032

Lamb AL, Wilson GP, Leng MJ (2006) A review of coastal palaeoclimate and relative sea-level reconstructions using $\delta 13 \mathrm{C}$ and $\mathrm{C} / \mathrm{N}$ ratios in organic material. Earth-Sci Rev 75:29-57. https://doi.org/10.1016/j.earscirev.2005.10.003

Laskar J, Robutel P, Joutel F, Gastineau M, Correia ACM, Levrard B (2004) A long-term numerical solution for the insolation quantities of the Earth. Astron Astrophys 428:261-285. https://doi.org/10.1051/0004-6361: 20041335

Leyden B, Brenner M, Curtis JH, Piperno D, Whitmore T, Dahlin BH (1996) A Record of Long-and Short-Term Climatic Variation from NorthwestYucatán: Cenote San José Chulchaca. In: Fedick SL (ed) The Managed Mosaic: Ancient Maya Agriculture and Resource Use. University of Utah Press, Salt Lake City, pp 30-50

Lowery JG, Rankey EC (2017) Nearshore Influences of Upwelling, Waves, and Currents On A Tropical Carbonate Ramp: Holocene, Northwestern Yucatán Shelf, Mexico. J Sediment Res 87:546-566. https://doi.org/10. 2110/jsr.2017.32

Martinez A, Hernández-Terrones L, Rebolledo-Vieyra M, Paytan A (2018) Impact of carbonate saturation on large 
Caribbean benthic foraminifera assemblages. Biogeosciences 15:6819-6832. https://doi.org/10.5194/bg-156819-2018

Medina-Elizalde M, Burns SJ, Lea DW, Asmerom Y, von Gunten L, Polyak V, Vuille M, Karmalkar A (2010) High resolution stalagmite climate record from the Yucatán Peninsula spanning the Maya terminal classic period. Earth Planet Sci Lett 298:255-262. https://doi.org/10. 1016/j.epsl.2010.08.016

Metcalfe SE, Barron JA, Davies SJ (2015) The Holocene history of the North American Monsoon: 'known knowns' and 'known unknowns' in understanding its spatial and temporal complexity. Quat Sci Rev 120:1-27. https://doi. org/10.1016/j.quascirev.2015.04.004

Murray JW (2006) Ecology and applications of benthic foraminifera. Cambridge University Press, Cambridge

Murray JW, Alve E (1999) Taphonomic experiments on marginal marine foraminiferal assemblages: how much ecological information is preserved? Palaeogeogr Palaeoclimatol Palaeoecol 149:183-197. https://doi.org/ 10.1016/S0031-0182(98)00200-4

Oksanen J, Blanchet FG, Friendly M, Kindt R, Legendre P, McGlinn D, Minchin PR, O'Hara RB, Simpson GL, Solymos P, Stevens MHH, Szoecs E, Wagner H (2019) vegan: Community Ecology Package

Peros MC, Gregory B, Matos F, Reinhardt E, Desloges J (2015) Late Holocene record of lagoon evolution, climate change, and hurricane activity from southeastern Cuba. Holocene 25:1483-1497. https://doi.org/10.1177/ 0959683615585844

Peros MC, Reinhardt EG, Davis AM (2007) A 6000-year record of ecological and hydrological changes from Laguna de la Leche, north coastal Cuba. Quat Res 67:6982. https://doi.org/10.1016/j.yqres.2006.08.004

Perry E, Marin L, McClain J, Velazquez G (1995) Ring of Cenotes (sinkholes), northwest Yucatan, Mexico: Its hydrogeologic characteristics and possible association with the Chicxulub impact crater. Geology 23:17-20. https://doi.org/10.1130/0091-7613(1995)023\%3c0017: ROCSNY\%3e2.3.CO;2

Perry E, Oliman GV, Wagner N (2011) Preliminary Investigation of Groundwater and Surface Water Geochemistry in Campeche and Southern Quintana Roo. In: Spring ÚO (ed) Water Resources in Mexico. Springer, Berlin, pp 8797

Perry E, Oliman GV, Socki RA (2003) Hydrogeology of the Yucatán Peninsula. In: Gómez-Pompa A, Allen MF, Fedick SL, Jiménez-Osornio JJ (eds) The Lowland Maya area: three millennia at the human-wildland interface. Food Products Press, New York, pp 115-138

Perry E, Velazquez-Oliman G, Marin L (2002) The Hydrogeochemistry of the Karst Aquifer System of the Northern Yucatan Peninsula, Mexico. Int Geol Rev 44:191-221. https://doi.org/10.2747/0020-6814.44.3.191

Phleger FB, Ayala-Castanares A (1971) Processes and History of Terminos Lagoon, Mexico. AAPG Bull 55:2130-2140

Polk JS, van Beynen PE, Reeder PP (2007) Late Holocene environmental reconstruction using cave sediments from Belize. Quat Res 68:53-63. https://doi.org/10.1016/j. yqres.2007.03.002
R Core Team (2020) R: A Language and Environment for Statistical Computing. R Foundation for Statistical Computing, Vienna, Austria

Roy PD, Torrescano-Valle N, Islebe GA, Gutiérrez-Ayala LV (2017) Late Holocene hydroclimate of the western Yucatan Peninsula (Mexico). J Quat Sci 32:1112-1120. https://doi.org/10.1002/jqs.2988

Schönfeld J, Alve E, Geslin E, Jorissen F, Korsun S, Spezzaferri S (2012) The FOBIMO (FOraminiferal BIoMOnitoring) initiative-Towards a standardised protocol for soft-bottom benthic foraminiferal monitoring studies. Mar Micropaleontol 94-95:1-13. https://doi.org/10.1016/ j.marmicro.2012.06.001

Sen Gupta BK (1999) Modern Foraminifera. Kluwer Academic Publishers, Boston

Shaw CE, Benson L (2015) Possible tsunami deposits on the Caribbean Coast of the Yucatan Peninsula. J Coast Res 31 (1306):1316. https://doi.org/10.2112/JCOASTRES-D-1400084.1

Smith DE, Harrison S, Jordan JT (2013) Sea level rise and submarine mass failures on open continental margins. Quat Sci Rev 82:93-103. https://doi.org/10.1016/j.quas cirev.2013.10.012

Sutton RT, Hodson DLR (2005) Atlantic Ocean Forcing of North American and European Summer Climate. Science 309:115-118. https://doi.org/10.1126/science.1109496

Swarzenski PW, Baskaran M, Rosenbauer RJ, Orem WH (2006) Historical trace element distribution in sediments from the Mississippi River delta. Estuaries Coasts 29:1094-1107

Tamalavage AE, van Hengstum PJ, Louchouarn P, Molodtsov S, Kaiser K, Donnelly JP, Albury NA, Fall PL (2018) Organic matter sources and lateral sedimentation in a Bahamian karst basin (sinkhole) over the late Holocene: Influence of local vegetation and climate. Palaeogeogr Palaeoclimatol Palaeoecol 506:70-83. https://doi.org/10. 1016/j.palaeo.2018.06.014

Vela-Pelaez AA, Torrescano-Valle N, Islebe GA, Mas JF, Weissenberger H (2018) Holocene precipitation changes in the Maya forest, Yucatán peninsula, Mexico. Palaeogeogr Palaeoclimatol Palaeoecol 505:42-52. https://doi. org/10.1016/j.palaeo.2018.05.024

Verardo DJ, Froelich PN, McIntyre A (1990) Determination of organic carbon and nitrogen in marine sediments using the Carlo Erba NA-1500 analyzer. Deep Sea Res Part Oceanogr Res Pap 37:157-165. https://doi.org/10.1016/01980149(90)90034-S

Wahl D, Byrne R, Anderson L (2014) An 8700 year paleoclimate reconstruction from the southern Maya lowlands. Quat Sci Rev 103:19-25. https://doi.org/10.1016/j.quas cirev.2014.08.004

Wahl D, Byrne R, Schreiner T, Hansen R (2006) Holocene vegetation change in the northern Peten and its implications for Maya Prehistory. Quat Res 65:380-389. https://doi.org/10.1016/j.yqres.2005.10.004

Webster JW, Brook GA, Railsback LB, Cheng H, Edwards RL, Alexander C, Reeder PP (2007) Stalagmite evidence from Belize indicating significant droughts at the time of Preclassic Abandonment, the Maya Hiatus, and the Classic Maya collapse. Palaeogeogr Palaeoclimatol Palaeoecol 250:1-17. https://doi.org/10.1016/j.palaeo.2007.02.022 
Whitmore TJ, Brenner M, Curtis JH, Dahlin BH, Leyden BW (1996) Holocene climatic and human influences on lakes of the Yucatan Peninsula, Mexico: an interdisciplinary, palaeolimnological approach. The Holocene 6:273-287. https://doi.org/10.1177/095968369600600303

Young MB, Gonneea ME, Fong DA, Moore WS, HerreraSilveira J, Paytan A (2008) Characterizing sources of groundwater to a tropical coastal lagoon in a karstic area using radium isotopes and water chemistry. Mar Chem 109:377-394. https://doi.org/10.1016/j.marchem.2007.07. 010
Young M, Gonneea ME, Herrera-Silveira J, Paytan A (2005) Export of dissolved and particulate carbon and nitrogen from a mangrove-dominated lagoon Yucatan Peninsula Mexico. Int J Ecol Environ Sci 31:189-202

Publisher's Note Springer Nature remains neutral with regard to jurisdictional claims in published maps and institutional affiliations. 